Document downloaded from:

http://hdl.handle.net/10251/140897

This paper must be cited as:

Gonzalez-Alvarez, M.; Coll Merino, MC.; Gonzalez-Alvarez, I.; Giménez Morales, C.; Aznar, E.; Martínez-Bisbal, M.; Lozoya Agulló, I.... (2017). Gated Mesoporous Silica Nanocarriers for a "two-Step" Targeted System to Colonic Tissue. Molecular Pharmaceutics. 14(12):44424453. https://doi.org/10.1021/acs.molpharmaceut.7b00565

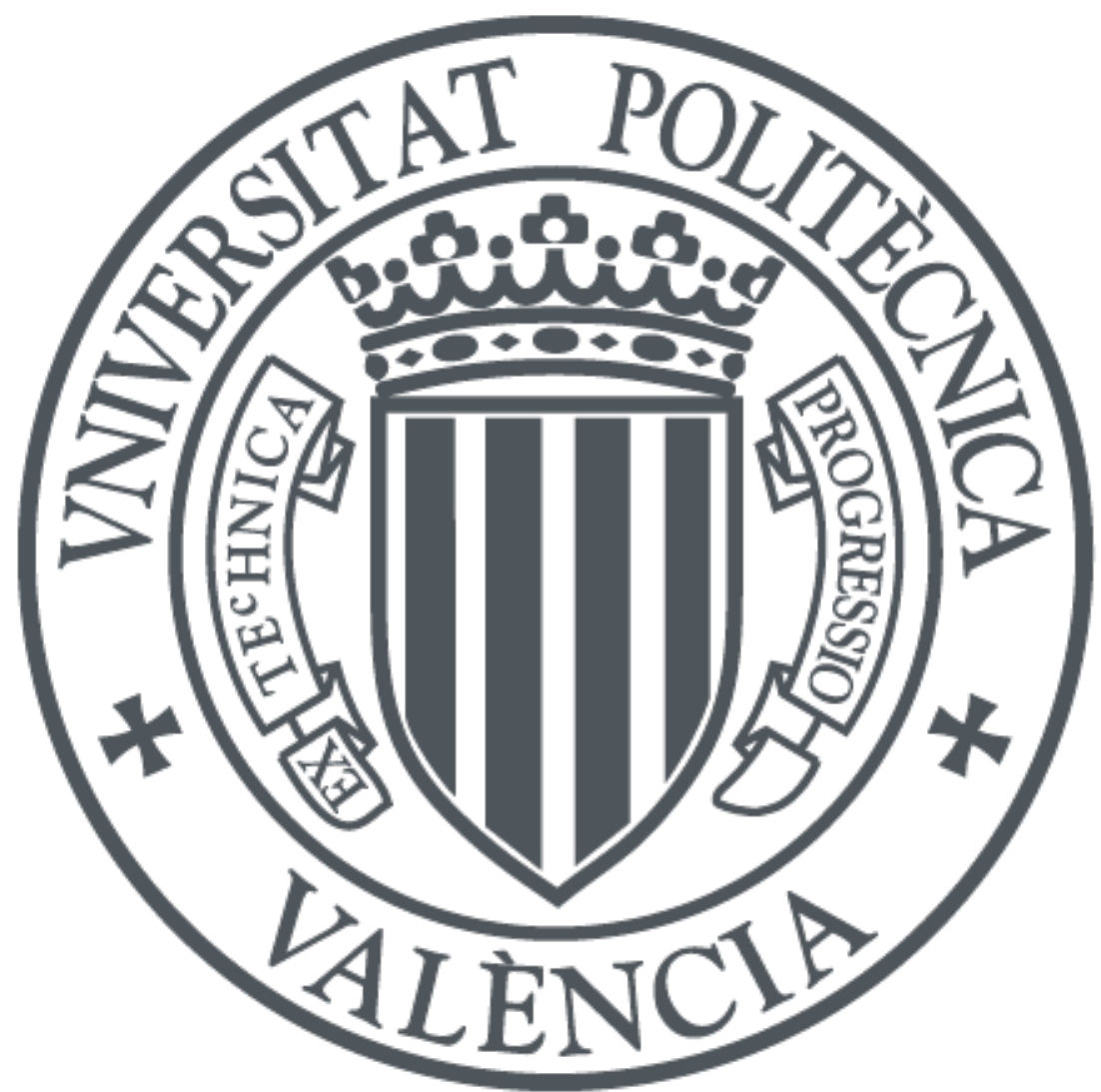

The final publication is available at

https://doi.org/10.1021/acs.molpharmaceut.7b00565

Copyright American Chemical Society

Additional Information 


\section{GATED MESOPOROUS SILICA NANOCARRIERS FOR A “TWO-STEP” TARGETED SYSTEM TO COLONIC TISSUE}

Marta González-Alvarez ${ }^{\mathrm{a}}$, Carmen Coll ${ }^{\mathrm{b}, \mathrm{c}}$, Isabel Gonzalez-Alvarez ${ }^{\mathrm{a}}$, Cristina

Giménez $^{\mathrm{b}, \mathrm{c}}$, Elena Aznar ${ }^{\mathrm{b}, \mathrm{c}}$, M.Carmen Martínez-Bisbal ${ }^{\mathrm{b}, \mathrm{c}, \mathrm{d}}$, Isabel Lozoya-Agulló, Marival Bermejo ${ }^{\mathrm{a}}$, Ramón Martínez-Máñez ${ }^{\mathrm{b}, \mathrm{c}, \mathrm{d}, \mathrm{e}}$ and Félix Sancenón ${ }^{\mathrm{b}, \mathrm{c}, \mathrm{d}, \mathrm{e}}$

${ }^{a}$ Departamento de Ingeniería. Área Farmacia y Tecnología Farmacéutica. Universidad Miguel Hernández, Elche.

${ }^{\mathrm{b}}$ Instituto Interuniversitario de Investigación de Reconocimiento Molecular y Desarrollo Tecnológico (IDM). Universitat Politècnica de València, Universitat de València, Camino de Vera s/n, 46022-Valencia, Spain.

${ }^{c}$ CIBER en Biotecnología, Biomateriales y Nanomedicina (CIBER-BBN)

${ }^{\mathrm{d}}$ Unidad Mixta de Investigación en Nanomedicina y Sensores Universitat Politècnica de València, IIS La Fe de Valencia, Spain

${ }^{\mathrm{e}}$ Departamento de Química, Universitat Politècnica de València

* Corresponding autor: Ramón Martínez-Máñez. Instituto Interuniversitario de Investigación de Reconocimiento Molecular y Desarrollo Tecnológico (IDM). Universitat Politècnica de València, Universitat de València. Camino de Vera s/n, 46022 - Valencia, Spain. e-mail: rmaez@ qim.upv.es, Phone: + 34963877343 (ext. 73432) 


\begin{abstract}
Colon targeted drug delivery is highly relevant not only to treat colonic local diseases, but also for systemic therapies. Mesoporous silica nanoparticles (MSNs) have been demonstrated as useful systems for controlled drug release given their biocompatibility and the possibility of designing gated systems able to release cargo only upon the presence of certain stimuli. We report herein the preparation of three gated MSNs able to deliver their cargo triggered by different stimuli (redox ambient (S1), enzymatic hydrolysis (S2) and a surfactant or being in contact with cell membrane (S3)), and their performance in solution and in vitro with Caco-2 cells. safranin O dye was used as a model drug to track cargo fate. Studies of cargo permeability in Caco-2 monolayers demonstrated that intracellular safranin O levels were significantly higher in Caco-2 monolayers when using MSNs compared to those of free dye. Internalization assays indicated that $\mathbf{S 2}$ nanoparticles were taken up by cells via endocytosis. $\mathbf{S 2}$ nanoparticles were selected for in vivo tests in rats. For in vivo assays, capsules were filled with S2 nanoparticles and coated with Eudragit $® F S 30$ D to target colon. The enteric coated capsule containing the MSNs was able to deliver $\mathbf{S 2}$ nanoparticles in colon tissue (first step) and then nanoparticles were able to deliver safranin $\mathrm{O}$ inside de colonic cells after the enzymatic stimuli (second step). This result in high levels of safranin $\mathrm{O}$ in colonic tissue combined with low dye levels in plasma and body tissues. The results suggested that this combination of enzyme-responsive gated MSNs and enteric coated capsules may improve the absorption of drugs in colon to treat local diseases with a reduction of systemic effects.
\end{abstract}

\title{
KEYWORDS
}

Colon targeting; mesoporous silica nanoparticles; drug delivery; colonic disease; gated materials 


\section{INTRODUCTION}

Research to develop colon-targeted drug delivery strategies is highly relevant not only to treat colonic local diseases, but also for systemic therapy. In colonic local diseases, treatment with a site-specific delivery system improves therapy effectiveness, a required dose can be lowered and fewer side effects appear. Local disorders that affect the colon, such as inflammatory bowel diseases (IBD), colorectal cancer and infections, are common worldwide and cause major health problems. IBD and colorectal cancer are a major cause of morbidity and mortality in western countries. IBD is a group of chronic relapsing gastrointestinal diseases, including ulcerative colitis and Crohn's disease, both characterized by cycles of relapsing and remitting mucosal inflammation. ${ }^{1}$ There is no current cure for IBD, and today's therapies focus on maintaining remission from inflammatory episodes. Therapy can induce and maintain remission for a time, but $70 \%$ of IBD patients require surgery. ${ }^{2}$ Moreover, conventional oral therapies result in adverse effects and toxicity because of the drug's distribution around the body. Colorectal cancer is the third most commonly diagnosed cancer in males and the second in females, with 1.4 million cases and 693,900 deaths estimated in $2012 .{ }^{3}$ Current treatment is based on specific systemic chemotherapy or chemotherapy administered directly into the hepatic artery in an attempt to reach higher levels in tumor tissue. The drugs of choice for colorectal cancer are usually 5-fluorouracil, irinotecan, oxaliplatin, or their combinations. Besides side effects, these drugs have specific adverse effects, such as hand-foot syndrome, skin painful ulcer (5-fluoracil), ${ }^{4,5}$ neuropathy, painful hands and feet, esophageal sensitivity to cold and hot substances, difficulties in swallowing liquids (oxaliplatin), ${ }^{6}$ and diarrhea (irinotecan). ${ }^{7}$

As before mentioned, colon targeting would not only improve treatment of colonic diseases like colorectal cancer and IBD, among others, but would also constitute a potential alternative route for the systemic absorption of conventional and labile drugs, peptides and proteins. The colon is characterized by singular physiological factors inside the gastrointestinal (GI) tract, e.g., lower peptidase activity, ${ }^{8}$ reduced enzymatic activity, ${ }^{9}$ near neutral $\mathrm{pH}^{10}$ and long transit time. ${ }^{11,12}$

Diverse colon targeting strategies must be resistant to prevent drug release in the upper gastrointestinal regions, and also responsive to specific triggering mechanisms to ensure prompt drug release in the colon. ${ }^{8}$ Conventional strategies to perform colon target drug 
delivery usually rely on colonic physiological features, such as colonic bacterial enzymes, GI transit time, ${ }^{13}$ pressure arising from intestinal contractions, ${ }^{14}$ or $\mathrm{pH}$ gradient. ${ }^{8}$ The most commonly used $\mathrm{pH}$-dependent coating polymer to facilitate drug delivery to the colonic region is methacrylic acid plus methyl methacrylate ester copolymer, marketed as Eudragit S, soluble at pH>7.0 (Rohm Pharma, Darmstadt, Germany).

Once the drug is delivered in colon, absorption is highly challenging, especially with peptides, proteins and nucleic acids, given poor mucosal membrane permeability. ${ }^{15}$ The high molecular weight, hydrophilicity and hydrogen-bonding capability of these molecules complicate their absorption across the mucus-covered epithelium. ${ }^{15}$ Different formulation strategies for successful mucosal drug delivery exist. Among them, diverse examples of nano- and microparticles have been tested. Nanoparticles generally have a high surface-to-volume ratio, and their relatively small size enables deep tissue infiltration and, thus, potentially good mucus penetration. ${ }^{15}$ Drug release can occur in such a way that it allows the mucosal absorption of the drug, or the particle can be taken up and transported into and/or across the mucosa prior to drug release.

Mesoporous silica nanoparticles (MSNs) ${ }^{16}$ have been used as inorganic scaffolds for the storage and release of drugs and organic molecules. ${ }^{17-19}$ The unique features of MSNs include high stability, biocompatibility, homogeneous porosity, high inertness and functionalization ease, which confer them useful properties as potential drug containers. $^{20,21}$ MSNs can be prepared in a wide range of sizes with tailored-made pores of around 2-10 $\mathrm{nm}$. MSNs can be functionalized to design gated nanoparticles able to display "zero release" until a suitable stimulus is applied, which makes this technology optimal to develop new effective drug-delivery nanodevices. ${ }^{18,21}$ Chemical triggers, such as presence of anions, ${ }^{22-26}$ redox molecules, ${ }^{27-32}$ antigens, ${ }^{33-36}$ oligonucleotides, ${ }^{37-}$ ${ }^{40}$ and enzymes, ${ }^{41-44}$ have been used to develop gated materials with controlled-release features.

In this context, and taking into account the substantial interest shown in the design of delivery systems that target the colon, this work presents the preparation of three different gated MSNs loaded with safranin O (as a model drug) and capped with molecules that contain a disulphide bond $(\mathbf{S 1}),{ }^{45}$ hydrolyzed starch $(\mathbf{S 2}){ }^{43}$ and a lipid bilayer $(\mathbf{S 3}) .{ }^{46}$ Uncapping of the nanoparticles in the presence of certain stimuli was 
studied in both aqueous solutions and Caco-2 cells. Moreover, the permeability of safranin O when encapsulated in $\mathbf{S 1}, \mathbf{S 2}$ and $\mathbf{S 3}$, compared to that of free dye, in Caco-2 monolayers (a model for drug transport across the intestinal mucosa) was also studied. Finally, in vivo experiments, in which $\mathbf{S 2}$ was included in an enteric coated capsule with Eudragit @ FS $30 \mathrm{D}$ in rats to study cargo biodistribution (e.g., safranin O), were carried out.

\section{MATERIAL AND METHODS}

\subsection{Chemicals.}

Tetraethylortosilicate (TEOS), $n$-cetyltrimethylammoniumbromide (CTABr), sodium hydroxide $(\mathrm{NaOH})$, tris(2-carboxyethyl)phosphine hydrochloride (TCEP), pancreatin from porcine pancreas, dodecyltrimethylammonium bromide (DTABr), 2,2'-dipyridyl disulphide, 1,2-dioleoyl-sn-glycero-3-phosphocholine (DOPC), safranin O, fluorescein isotiocianate (FITC), $O$-(2-mercaptoethyl)-O'-methylhexa(ethylene glicol), 3aminopropyltriethoxysilane (APTES), (3-mercaptopropyl)trimethoxysilane and 3-(4,5dimetiltiazol-2-ilo)-2,5-difeniltetrazole bromide (MTT) were provided by Aldrich. Glucidex 29 (10\% glucose, 9\% maltose, 81\% oligosaccharides and polysaccharides) was provided by Roquette. Tetraethylammonium bromide (99\%) was provided by Merck. Anhydrous ethanol was obtained by VWR international Eurolab. Chloroform and acetonitrile were provided by Scharlab. Eutanax®, HBSS (Hank’s Balanced Salt Solution), hepes, penicillin G, streptomycin, fetal bovine serum, DMEM Glutamax, PBS-EDTA and trypsin-EDTA were supplied by GIBCO. Ultrapure water was obtained in a Millipore QPAK system.

\section{Synthesis of MSNs}

For the synthesis of MSNs, CTABr (1.00 g, $2.74 \mathrm{mmol})$ was dissolved in $480 \mathrm{~mL}$ of distilled water, followed by the addition of $3.5 \mathrm{~mL}$ of $\mathrm{NaOH} 2.00 \mathrm{M}$. This solution was heated to $80^{\circ} \mathrm{C}$ and TEOS (5 mL, $25.7 \mathrm{mmol}$ ) was added dropwise. The mixture was stirred for $2 \mathrm{~h}$ at this temperature. A white precipitate was obtained, which was isolated by centrifugation. Finally, the solid was washed with distilled water and dried at $70^{\circ} \mathrm{C}$ (MSN as-synthesized). To prepare the final porous material (MSNs), the as-synthesized 
solid was calcined at $550^{\circ} \mathrm{C}$ for $5 \mathrm{~h}$ in an oxidant atmosphere to remove the template phase.

\section{Synthesis of $\mathbf{S 1}$}

MSNs were loaded with safranin $\mathrm{O}$ dye and coated with molecules that contained a disulphide bond. Cargo was released in a reducing environment (S1 nanoparticles). MSNs (350 mg) were suspended in a solution of safranin O $(98.23 \mathrm{mg}, 0.28 \mathrm{mmol})$ in acetonitrile $(8.7 \mathrm{~mL})$ in a round-bottomed flask. The mixture was stirred for $24 \mathrm{~h}$ at room temperature, filtered off and dried under vacuum. The safranin O-loaded MSNs $(340 \mathrm{mg})$ were re-suspended in acetonitrile $(10.2 \mathrm{~mL})$ in the presence of excess dye, and (3-mercaptopropyl)trimethoxysilane $(632.48 \mu \mathrm{L}, 3.4 \mathrm{mmol})$ was added. The suspension was stirred for $5.5 \mathrm{~h}$ at room temperature. Then 2,2'-dipyridyl disulfide (600 mg, 2.7 mmol) was added to the reaction mixture. After stirring for $12 \mathrm{~h}$ at room temperature, the resulting solid was filtered off and dried under vacuum. Finally, a mixture of this prepared solid (150 mg) and $O$-(2-Mercaptoethyl)- $O$ '-methyl-hexa(ethylene glycol) (0.3 mmol) was suspended in acetonitrile $(4.3 \mathrm{~mL})$ in the presence of an excess of safranin O. The mixture was stirred for $12 \mathrm{~h}$ and final support $\mathbf{S 1}$ was isolated by centrifugation, washed with abundant water and dried at $40^{\circ} \mathrm{C}$ for $12 \mathrm{~h}$.

\section{Synthesis of $\mathbf{S} \mathbf{2}$ and $\mathbf{S} \mathbf{2 b}$}

MSNs were loaded with safranin O and coated with a starch derivative. Cargo delivery occurred via starch hydrolysis in the presence of amylase enzyme (S2 nanoparticles). First, the starch derivative was synthesized. Hydrolyzed starch Glucidex 29 (1.0 g) was maintained for $1 \mathrm{~h}$ under vacuum in a round-bottomed flask to remove the adsorbed water. Afterward it was suspended in anhydrous ethanol $(50 \mathrm{~mL})$ and APTES $(1.17 \mathrm{~mL}$, $5 \mathrm{mmol}$ ) was added. The reaction mixture was stirred in an inert atmosphere for $24 \mathrm{~h}$ at room temperature and then heated at $60^{\circ} \mathrm{C}$ for $30 \mathrm{~min}$. The solvent was evaporated under reduced pressure to give a white solid (Glu-29). ${ }^{43}$

MSNs (200 mg) were suspended in a safranin O solution (120 mg, $0.34 \mathrm{mmol})$ in distilled water $(6 \mathrm{~mL})$ in a round-bottomed flask. The mixture was stirred for $24 \mathrm{~h}$ at room temperature. Then excess hydrolyzed starch derivative (Glu-29, $200 \mathrm{mg}$ ) was 
added, and the final mixture was stirred for $5.5 \mathrm{~h}$ at room temperature. Finally, solid S2 was isolated by centrifugation, washed with abundant water, and dried at $40^{\circ} \mathrm{C}$ for $12 \mathrm{~h}$.

MSNs, without safranin O but covalently marked with fluorescein and functionalized with Glu-29, were also prepared (S2b). FITC (18 mg) and APTES (10 $\mu \mathrm{l})$ were reacted in $1 \mathrm{ml}$ of anhydrous ethanol in the dark for $4 \mathrm{~h}$. Next $0.5 \mathrm{~mL}$ of the solution was added to MSNs (200 mg), previously suspended in acetonitrile $(5 \mathrm{~mL})$, in a round-bottomed flask. The mixture was stirred for $12 \mathrm{~h}$ at room temperature. The solid was isolated by centrifugation and washed with ethanol in a Soxhlet apparatus to eliminate excess fluorescein. The FITC-labeled MSNs were dried at $40^{\circ} \mathrm{C}$ for $12 \mathrm{~h}$. Then excess Glu-29 $(150 \mathrm{mg})$ was added to the FITC-labeled MSNs $(150 \mathrm{mg})$ suspended in distilled water $(4 \mathrm{~mL})$ in a round-bottomed flask. The mixture was stirred for $5.5 \mathrm{~h}$ at room temperature. Solid $\mathbf{S 2 b}$ was isolated by centrifugation, washed with abundant water, and dried at $40^{\circ} \mathrm{C}$ for $12 \mathrm{~h}$.

\section{Synthesis of $\mathbf{S 3}$}

MSNs were loaded with safranin $\mathrm{O}$ and capped with a lipid bilayer. Cargo was released in the presence of a surfactant or being in contact with the cell membrane ( $\mathbf{S 3}$ nanoparticles). MSNs (100 mg) and safranin O (60 mg, $0.17 \mathrm{mmol})$ were suspended in distilled water $(3 \mathrm{~mL})$ and the mixture was stirred for $24 \mathrm{~h}$ at room temperature. Afterward a suspension of liposomes was prepared. For this purpose, DOPC (8.9 mg, $0.01 \mathrm{mmol})$ was dissolved in chloroform $(2 \mathrm{~mL})$ in a glass vial. Chloroform was evaporated under a nitrogen flow, and the lipid was dried under vacuum for $1 \mathrm{~h}$ to remove any residual chloroform, and to obtain films. Then PBS 0.25x (4 mL) was added and the medium was sonicated to obtain a cloudy lipid suspension. This cloudy liquid was added to the suspension of the MSNs by manual pipetting. The mixture was allowed to rest at room temperature overnight. Finally, nanoparticles were isolated by centrifugation, washed with abundant water and dried at $40^{\circ} \mathrm{C}$ for $12 \mathrm{~h}$.

\subsection{Characterization}

The synthesized materials were characterized by diverse techniques. The powder X-ray diffraction (PXRD) studies were performed in a Bruker D8 Advanced diffractometer using $\mathrm{CuK} \alpha$ radiation to determine the geometry of the empty and loaded MSNs, and to 
confirm that the loading process and functionalization did not damage the mesoporous scaffolding. The transmission electron microscopy (TEM) images were obtained with JEOL JEM-1010 to confirm the mesoporous structure in the final functionalized solids. $\mathrm{N}_{2}$ adsorption-desorption isotherms were carried out in a Micromeritics ASAP 2010 automated sorption analyzer. Samples were degassed at $120^{\circ} \mathrm{C}$ under vacuum overnight. The specific surface area was calculated from the adsorption data by the BET model. Pore size was determined following the BJH method. Elemental analyses, thermogravimetric analyses (TGA) and ${ }^{1} \mathrm{H}-\mathrm{NMR}$ spectra were used to determine the content of the gating moieties and safranin O. The TGA analyses were performed by TGA/SDTA 851e Mettler Toledo equipment, using an oxidant atmosphere (air, 80 $\mathrm{mL} / \mathrm{min}$ ) with a heating program that consisted of a heating ramp of $10^{\circ} \mathrm{C}$ per minute from 393 to $1273 \mathrm{~K}$, and a isothermal heating step at this temperature for $30 \mathrm{~min}$. The ${ }^{1} \mathrm{H}-\mathrm{NMR}$ experiments were performed in a Bruker AV400 spectrometer after dissolving the corresponding sample in $\mathrm{NaOD} / \mathrm{D}_{2} \mathrm{O}$ in the presence of tetraethylammonium bromide as an internal standard. To determine the zeta potential of the bare and functionalized nanoparticles (S1-S3), a Zetasizer Nano ZS equipment (Malvern Instruments, Malvern, UK) was used. Samples were dispersed in distilled water at a concentration of $1 \mathrm{mg} / \mathrm{mL}$. Before each measurement, samples were sonicated for $2 \mathrm{~min}$ to preclude aggregation. The zeta potential was calculated from the particle mobility values by applying the Smoluchowski model. The measurements were performed at 25 ${ }^{\circ} \mathrm{C}$ and performed in triplicate. Dynamic light scattering (DLS) studies for the determination of particle size were conducted at $25^{\circ} \mathrm{C}$ in a Malvern Zetasizer Nano ZS instrument; all the measurements were taken in triplicate on previously sonicated water dispersions.

\subsection{Delivery studies.}

Delivery studies from $\mathbf{S 1}, \mathbf{S 2}$ and $\mathbf{S 3}$ in solution were performed using appropriate stimuli. The delivery experiments of $\mathbf{S 1}$ were carried out in solution using TCEP as a reducing agent. Specifically, $\mathbf{S 1}(0.5 \mathrm{mg})$ was suspended in distilled water $(2.7 \mathrm{~mL}, \mathrm{pH}$ 7.5) and $30 \mu \mathrm{L}$ of TCEP solution $(10 \mathrm{mM})$ were added. For $\mathbf{S 2}$, the delivery experiments in the presence of pancreatin as a stimulus were carried out. $\mathbf{S 2}(4 \mathrm{mg})$ was suspended in distilled water $(7.5 \mathrm{~mL}, \mathrm{pH} 7.5)$ and $2.5 \mathrm{~mL}$ of enzyme solution $(0.4 \mathrm{~g}$ pancreatin / $100 \mathrm{~mL}$ ) were added. For the $\mathbf{S 3}$ material, delivery experiments were 
carried out in solution using surfactant DTABr as a stimulus. $\mathbf{S 3}(0.5 \mathrm{mg})$ was suspended in distilled water $(2.7 \mathrm{~mL}, \mathrm{pH} 7.5)$ and DTABr solution $(10 \mathrm{mM})$ was added. Suspensions of $\mathbf{S 1}, \mathbf{S 2}$ and $\mathbf{S 3}$ were stirred and the amount of dye released from the different materials in the presence of the respective stimuli was determined by measuring the safranin $\mathrm{O}$ emission at $575 \mathrm{~nm}$ in the solution according to time. In all cases nanoparticles were removed by centrifugation (13000 rpm, 3 min). Identical experiments using solids $\mathbf{S 1}, \mathbf{S 2}$ and $\mathbf{S 3}$, but in the absence of stimuli, were also carried out.

\subsection{In vitro cytotoxicity studies}

The Caco-2 cell line (ATCC) was selected to perform studies of nanoparticles in cells according to their ability to form simulative intestinal epithelial cell monolayers, which is useful to study crossing process-related transport mechanisms. ${ }^{15,47,48}$ The ability of MSNs and coated particles $\mathbf{S 1}, \mathbf{S 2}$ and $\mathbf{S 3}$ to interfere with the growth of Caco-2 cells was determined in vitro by the MTT method. ${ }^{49}$ The effect of doxorubicin $(10 \mathrm{mM})$ as a positive control was also studied by the MTT method. The mitochondria of living cells are able to convert MTT (a yellow-colored compound) into formazan (a blue-colored compound). Blue metabolite appearance can be spectrophotometrically quantified and the absorbance value is proportional to the remaining living cells.

Caco-2 cells (38 passages) were grown in DMEM high glucose supplemented with $1 \%$ of non-essential amino acids, $10 \%$ fetal bovine serum and $1 \%$ penicillin/streptomycin. 25,000 cells per well were seeded in a total volume of $200 \mu \mathrm{L}$ of culture medium in 96well microtiter plates with flat-bottomed wells. Cultures were incubated at $37^{\circ} \mathrm{C}$ in a $5 \%$ $\mathrm{CO}_{2}$ atmosphere. After $24 \mathrm{~h}$, the medium was replaced with fresh medium and MSNs S1, S2 or S3 were added ( $1 \mathrm{mg} / \mathrm{mL})$. Plates were incubated for $24 \mathrm{~h}, 48 \mathrm{~h}$, or $72 \mathrm{~h}$. Then $20 \mu \mathrm{L}$ of $5 \mathrm{mg} / \mathrm{mL}$ of the MTT solution were added to each well. Plates were incubated at $37^{\circ} \mathrm{C}$ for $3 \mathrm{~h}$ to allow formazan formation in wells. The liquid medium of each well was removed and the dark blue precipitate was dissolved in DMSO. Negative controls (solvent alone and untreated cells) were also performed. Assays were carried out in quadruplicate for each treatment. Absorbance was measured at $570 \mathrm{~nm}$ with a Labsystems Multiskan EX plate reader and the values were corrected with a reference to 
the measurement at $630 \mathrm{~nm}$. Data were expressed as a percentage of the absorbance of untreated cells.

\subsection{In vitro permeability studies and transport mechanism analysis}

In vitro permeability, intracellular uptake and inhibition studies were performed on the Caco-2 cell monolayers.

\section{Cell monolayer cultures}

The Caco- 2 cell monolayers were prepared by seeding 25,000 cells on a polycarbonate membrane placed on the base of transwell inserts (MILLICEL ${ }^{\circledR}$-PCF, surface area 4.2

$\mathrm{cm}^{2}, 0.4 \mu \mathrm{m}$ pore size).${ }^{50,51}$ Cultures were grown in Dulbecco's modified Eagle's media, as described previously, ${ }^{52,53}$ until confluence, and were maintained under standard conditions $\left(37^{\circ} \mathrm{C}\right.$ with $90 \%$ humidity and $\left.5 \% \mathrm{CO}_{2}\right)$ for $19-22$ days. The integrity of each cell monolayer was tested by measuring its transepithelial electrical resistance (TEER) value before and after each transport assay. The normal TEER values for the Caco-2 monolayers fall within the $500-750 \Omega \cdot \mathrm{cm}^{2}$ range. ${ }^{54}$ The cell monolayers with TEER values below $420 \Omega \cdot \mathrm{cm}^{2}$ were ruled out. Hank's balanced salt solution $(9.8 \mathrm{~g} / \mathrm{L})$ supplemented HEPES (5.96 g/L) was used for all the experiments after adjusting $\mathrm{pH}$ to 7.0. ${ }^{52,53}$ The system used, that contained a well with an insert placed therein, is formed by three compartments: (i) the apical compartment or donor chamber, which mimics the intestinal lumen; (ii) the basal compartment or receiving compartment, which represents plasma; (iii) the Caco-2 monolayer, which reproduced the intestinal barrier.

\section{Permeability studies of free safranin $O, S 1, S 2$ and $\mathbf{S 3}$}

The transport studies of free safranin O and encapsulated in nanoparticles S1, S2 and S3 $(1 \mathrm{mg} / \mathrm{mL})$ were studied at an equivalent dye concentration. The tested nanoparticles were loaded onto the donor side and buffer was added to the receiver chamber of each well. Assays were performed from the apical-to-basolateral direction in the Caco-2 cell monolayers to simulate physiological conditions. The 6-well plate that contained the inserts with the cell monolayers was placed into an orbital environmental shaker, and was maintained at a constant temperature $\left(37^{\circ} \mathrm{C}\right)$ and agitation rate $(50 \mathrm{rpm})$ throughout all the experiments. Assays were carried out at 1, 2, 4, 6, 9 and $24 \mathrm{~h}$. Safranin O was 
determined in the compartments by the collection of samples from donor and receptor compartments and from the Caco- 2 monolayers. To determine safranin $\mathrm{O}$ content in monolayers, cell lysates were obtained. Inserts were washed with saline solution $(\mathrm{NaCl}$ $0.9 \%$ in double distilled water) and membranes were first frozen in liquid nitrogen and later thawed in a water bath. Membranes were mixed with methanol and centrifuged (8000 rpm). Finally, the supernatant was taken and the amount of safranin $\mathrm{O}$ was determined.

The safranin $\mathrm{O}$ concentration in each compartment and in the monolayer cell lysates was determined by an HPLC analysis with a fluorescence detector $\left(\lambda_{\text {ex }} 520 \mathrm{~nm} ; \lambda_{\text {em }} 585\right.$ $\mathrm{nm}$ ) using a mobile phase (v/v) 30:70 acetonitrile:water with $1 \%$ of trifuoroacetic acid.

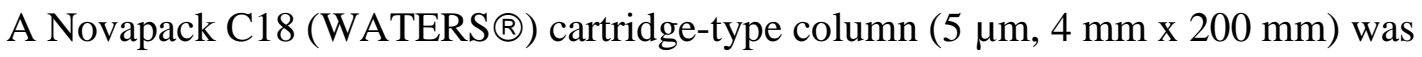
used.

Imaging study of the intracellular uptake of nanoparticles (studies with $\mathbf{S} \mathbf{2}$ and $S 2 b)$

The uptake of nanoparticles $\mathbf{S} 2$ and $\mathbf{S 2 b}$ into the Caco-2 monolayers was studied qualitatively by a fluorescence analysis. A suspension of nanoparticles $\mathbf{S 2}$ or $\mathbf{S 2} \mathbf{b}$ (1 $\mathrm{mg} / \mathrm{ml}$ ) was added to the donor compartment and was co-incubated in standard buffer (17.5 $\mu \mathrm{L}$ per $100 \mu \mathrm{L}$ of buffer). At scheduled times, donor compartments were emptied and monolayers were washed with PBS. The fluorescent images of each well were obtained by a high content multiwell plate reader Cytation 3 (BioTek Instruments, Inc.) and processed using the GEN 5 v2.05 (BioTek Instruments, Inc.) software. Images were captured by Texas red $\left(\lambda_{\mathrm{ex}} 585 \mathrm{~nm}, \lambda_{\mathrm{em}} 647 \mathrm{~nm}\right)$, green fluorescent protein $\left(\lambda_{\mathrm{ex}} 469 \mathrm{~nm}\right.$, $\lambda_{\mathrm{em}} 525 \mathrm{~nm}$ ) and bright field filters every 30 minutes over a total time of $24 \mathrm{~h}$ to determine safranin $\mathrm{O}$ and fluorescein distribution in the monolayers with suspension $\mathbf{S 2}$ and suspension $\mathbf{S 2 b}$, respectively.

\section{Mechanism analysis using inhibiting agents}

In order to evaluate the endocytosis mechanism involved in the uptake of $\mathbf{S 2}$ by Caco-2 cells, assays in both the presence and absence of different endocytosis inhibitors (chlorpromazine, nystatin or methyl- $\beta$-cyclodextrin $(\mathrm{M} \beta \mathrm{CD})+$ lovastatin) were carried out. Chlorpromazine is able to inhibit the endocytic process mediated by the receptor 
and clathrins. Nystatin inhibits caveolae/lipid raft-mediated endocytosis. The M $\beta C D$ and lovastatin mixture is used as an inhibitor of clathrin and caveolae-mediated endocytosis.

For this purpose, the Caco-2 monolayers were pre-incubated with $500 \mu \mathrm{L}$ of the different inhibitors (chlorpromazine $10 \mu \mathrm{g} / \mathrm{mL}$, nystatin $50 \mu \mathrm{g} / \mathrm{mL}$ and a mixture of M $3 C D 10 \mathrm{mM}$ and lovastatin $1 \mu \mathrm{g} / \mathrm{mL})$. After $1 \mathrm{~h}$, nanoparticles $\mathbf{S 2}(1 \mathrm{mg} / \mathrm{mL})$ were added to the apical side of the insert and mixtures were incubated for $2 \mathrm{~h}$. Assays in the absence of inhibitors were also performed. Safranin $\mathrm{O}$ was determined in the cell monolayer following the same procedures used before (vide ante).

\subsection{In vivo tissue distribution studies}

To assess the in vitro results, in vivo experiments with $\mathbf{S 2}$ (which showed the best performance in solution and in cells) in rats were carried out and safranin $\mathrm{O}$ biodistribution was studied. The animal study was approved by the Scientific Committee of the Faculty of Pharmacy of the Universidad Miguel Hernández, Elche (project reference DI-MBS-001-12) and followed the guidelines described in EC Directive 86/609, the Council of the Europe Convention ETS 123, and were in compliance with Spanish national laws about using animals in research (Spanish Royal Decree 223/ 1988, BOE 67, 18-3-98:8509-8511).

\section{Preparation of enteric-coated capsules}

The enteric capsules filled with S2 were coated with Eudragit@FS 30 D (an anionic copolymer of methyl acrylate, methyl methacrylate and methacrylic acid). Eudragit@FS $30 \mathrm{D}$ dissolves from $\mathrm{pH} 7.2$ allowing capsule disintegration. An aqueous dispersion $30 \%$ (w/w) was used for the coating experiments. The enteric capsules filled with $\mathbf{S 2}$ were coated using a spray system. Disintegration control assays were performed at different pHs $(1.2,4,5$ and 7.5$)$ in order to verify the proper behaviour of the coating. The capsules retained its structural integrity during 2 hours at $\mathrm{pH}=1.2,4$ and 5 but disintegrated in less than 10 minutes at $\mathrm{pH}=7.5$. Capsules coated with Eudragit@FS 30 $\mathrm{D}$ were maintained at low relative humidity to prevent sticking.

\section{Biodistribution assays}


Male rats were fasted for $4 \mathrm{~h}$ ( 24 rats). S2 were administered to rats (12 rats) orally at a dose of $40 \mathrm{mg}$ of $\mathbf{S 2}$ in an enteric capsule covered by Eudragit@FS 30 D. In a control group (12 rats), a $0.04 \mathrm{mg}$ dose of free safranin $\mathrm{O}$ was administered to each rat as solution orally. Animals were sacrificed at $24 \mathrm{~h}, 48 \mathrm{~h}$ and $72 \mathrm{~h}$ after administration (4 animals at each time and per administration type). Blood samples were withdrawn and several tissues (liver, kidneys and spleen) were excised.

Blood volume and tissue weight were measured. Tissue was washed with PBS and wiped with a filter paper. Then PBS was added by a 3-fold volume of tissue weight, and was homogenized in a glass homogenizer with a teflon pestle and mixed. Blood and the homogenate tissue were centrifuged at 3,000 rpm for $10 \mathrm{~min}$. After centrifuge the homogenate or blood, the supernatant was diluted with PBS, and was deproteinized with acetonitrile. Afterward the safranin $\mathrm{O}$ concentration in each sample was determined by HPLC analysis with a fluorescence detector $\left(\lambda_{\text {ex }} 520 \mathrm{~nm} ; \lambda_{\mathrm{em}} 585 \mathrm{~nm}\right)$ using a mobile phase (v/v) 30:70 acetonitrile:water with $1 \%$ of trifuoroacetic acid. A Novapack C18 (WATERS $\left.{ }^{\circledR}\right)$ cartridge-type column $(5 \mu \mathrm{m}, 4 \mathrm{~mm}$ x $200 \mathrm{~mm})$ was used.

\section{RESULTS AND DISCUSSION}

\subsection{Gated materials and delivery studies in solution}

In order to prepare the different gated nanodevices described herein, MSNs were selected as an inorganic support because of their homogenous porosity, strong inertness and well-known functionalization chemistries. Safranin O dye was loaded into the pores of MSNs to act as cargo. Polyethylene glycol (PEG) chains that contain a disulphide bond, ${ }^{45}$ hydrolyzed starch (Glu-29) ${ }^{43}$ or a lipid bilayer prepared with DOPC, ${ }^{46}$ were selected as switchable gate-like ensembles and used as capping ensembles on the external surface of materials to obtain solid $\mathbf{S 1}$, solid $\mathbf{S 2}$ and solid S3, respectively (see Figure 1). We expected to observe "zero cargo release" from these nanoparticles until the corresponding stimuli was applied; i.e. a reducing agent (for S1), pancreatin (a mixture of digestive enzymes, including amylase, lipase and protease) (for S2) and a surfactant or being in contact with cell membrane (for S3). 


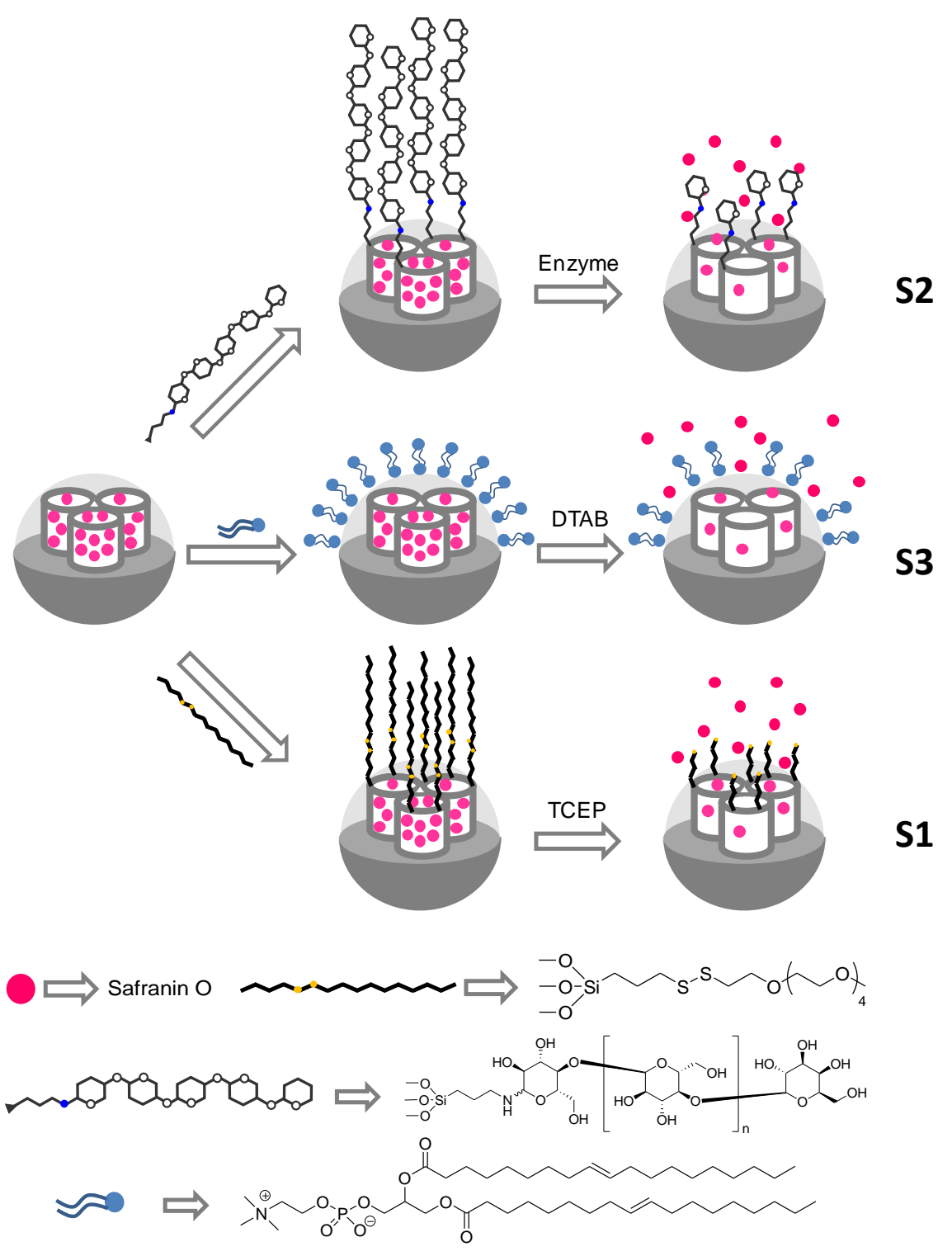

Figure 1. Preparation of gated mesoporous silica nanoparticles S1, S2 and S3 and the uncapping mechanism in the presence of the corresponding stimuli.

\section{Nanoparticles characterization}

MSNs and solids S1, S2 and S3 were characterized by standard techniques. The PXRD of MSNs as-synthesized showed four low-angle reflections typical of a hexagonal array, which can be indexed as (100), (110), (200), and (210) Bragg peaks (see Supporting Information). A significant displacement of the (100) peak in the PXRD of the MSNs was clearly noted and was related to further condensation of the silanol groups in the calcination step. The intensity of the (100) reflection in the final solids evidenced that the loading process with the dye and further functionalization did not damage the 
mesoporous 3D scaffolding. Presence of the mesoporous structure in the final solids was also confirmed by a TEM analysis (see Supporting Information).

The $\mathrm{N}_{2}$ adsorption-desorption isotherms of MSNs showed two sharp adsorption steps (see Supporting Information). The first step at an intermediate $\mathrm{P} / \mathrm{P}_{0}$ value $(0.1-0.3)$ was related to the nitrogen condensation inside the mesopores by capillarity. Absence of a hysteresis loop in this interval and the narrow BJH pore distribution suggested the existence of uniform cylindrical mesopores with a specific pore volume of $0.89 \mathrm{~cm}^{3} \mathrm{~g}^{-1}$, calculated by the BJH model on the adsorption branch of the isotherm. The application of the BET model resulted in a value for the total specific surface of $1067.7 \mathrm{~m}^{2} \mathrm{~g}^{-1}$. From the PXRD and porosimetry, the $\mathrm{a}_{0}$ cell parameter $(43.16 \AA)$, pore diameter $(2.64$ $\mathrm{nm})$ and wall thickness $(1.74 \mathrm{~nm})$ were calculated. A second feature appeared in the isotherm at a high relative pressure $\left(\mathrm{P} / \mathrm{P}_{0}>0.8\right)$, which corresponded to the filling of the large voids among MSNs, which presented a volume of $0.56 \mathrm{~cm}^{3} \mathrm{~g}^{-1}$ (calculated by the BJH model), which must be considered a textural-like porosity. In this case, the curves showed a characteristic H1 hysteresis loop and a wide pore size distribution.

The $\mathrm{N}_{2}$ adsorption-desorption isotherms of $\mathbf{S 1}, \mathbf{S 2}$ and $\mathbf{S 3}$ were typical of mesoporous systems with filled mesopores. The most relevant feature was the lack of a sharp step at low-medium relative pressure $\left(0.1<\mathrm{P} / \mathrm{P}_{0}<0.3\right)$. In fact these solids showed flat curves compared (on the same scale) to those of the starting MSNs parent material, which indicated significant pore blocking and the subsequent absence of appreciable mesoporosity. Consequently, a relatively low $\mathrm{N}_{2}$ adsorbed volume and decreases in the surface area were observed. A certain textural porosity was preserved in these final functionalized nanoparticles. The BET specific surface values, pore volumes, and pore sizes calculated from the $\mathrm{N}_{2}$ adsorption-desorption isotherms of the starting MSNs and S1, S2 and S3 are listed in Table 1. 
Table 1. BET-specific surface values, pore volumes and pore sizes calculated from the $\mathrm{N}_{2}$ adsorption-desorption isotherms for calcined MSNs, S1, S2 and S3.

\begin{tabular}{llcc}
\hline & $\begin{array}{l}\boldsymbol{S}_{\text {BET }} \\
\left(\mathbf{m}^{\mathbf{2}} \mathbf{g}^{\mathbf{- 1}}\right)\end{array}$ & $\begin{array}{c}\text { Pore volume }^{a} \\
\left(\mathbf{c m}^{\mathbf{3}} \mathbf{g}^{\mathbf{- 1}}\right)\end{array}$ & $\begin{array}{c}\text { Pore size }^{\boldsymbol{a}} \\
(\mathbf{n m})\end{array}$ \\
\hline MSN & 1067.7 & 0.89 & 2.64 \\
S1 & 99.0 & 0.25 & - \\
S2 & 120.8 & 0.39 & - \\
S3 & 312.3 & 0.69 & - \\
\hline
\end{tabular}

${ }^{a}$ Volume (V) and diameter (D) of mesopores.

Dynamic light scattering measurements resulted in values of hydrodynamic diameters of 107.1, 134.1, 229.9 and 195. $3 \mathrm{~nm}$ for the starting calcined MSNs and S1, S2 and S3, respectively (see Table 2). Moreover, zeta potential values of $-36.5,3.76,2.73$ and -3.14 $\mathrm{mV}$ were obtained for the calcined MSNs, S1, S2 and S3 nanoparticles (see also Table 2). Besides, PDI values of the different nanoparticles prepared are also shown in Table 2. As could be seen $\mathbf{S 2}$ nanoparticles, coated with the hydrolyzed starch, presented the higher hydrodynamic diameter. On the other hand calcined MSNs showed a negative zeta potential of $-36.5 \mathrm{mV}$ due to the presence of silanolate groups on its outer surface. In a clear contrast, the capped materials showed strong reductions in the $\mathrm{z}$ potential values (positive for $\mathbf{S 1}$ and $\mathbf{S 2}$ and negative for $\mathbf{S 3}$ ) due to the presence of different organic moieties grafted/adsorbed onto the external surface of the nanoparticles.

Table 2. Hydrodynamic diameter measured by DLS and surface zeta potential of MSN, S1, $\mathbf{S 2}$ and $\mathbf{S 3}$ solids.

\begin{tabular}{cccc}
\hline Solid & $\begin{array}{c}\text { Hydrodynamic } \\
\text { particle diameter } \\
(\mathbf{n m})\end{array}$ & $\begin{array}{c}\text { Zeta } \\
\text { potential } \\
\mathbf{( m V})\end{array}$ & PDI \\
\hline MSN & $107.1 \pm 39.2$ & $-36.5 \pm 0.64$ & 0.354 \\
S1 & $134.1 \pm 18.5$ & $3.76 \pm 0.24$ & 0.444 \\
S2 & $229.9 \pm 28.2$ & $2.73 \pm 0.52$ & 0.451 \\
S3 & $195.3 \pm 32.6$ & $-3.14 \pm 0.13$ & 0.548 \\
\hline
\end{tabular}


Finally, the content (see Table 3) of the different gating moieties and safranin O in S1, $\mathbf{S 2}$ and S3 was determined by combining elemental, thermogravimetric analyses and ${ }^{1} \mathrm{H}-\mathrm{NMR}$ studies after dissolving silica nanoparticles in a basic medium.

Table 3. Safranine O content and capping moieties for solids S1, S2 and S3 in $\mathrm{g} \mathrm{g}^{-1}$ solid.

\begin{tabular}{lllll}
\hline & Safranin O & Glu-29 & DOPC & PEG \\
\hline S1 & 0.058 & - & - & 0.273 \\
S2 & 0.036 & 0.079 & - & - \\
S3 & 0.121 & - & 0.023 & - \\
\hline
\end{tabular}

Delivery studies in solution of $\mathbf{S 1}, \mathbf{S} 2$ and $\mathbf{S 3}$

In a first step, and before performing in vitro studies in cells, the response of the different prepared gated MSNs in solution in both the presence and absence of triggering stimuli was studied. Similar systems to those studied herein have been reported in the literature. ${ }^{21}$ In particular, $\mathbf{S 1}$ was expected to be opened due to the reduction of the disulphide bond by TCEP, $\mathbf{S 2}$ was expected to deliver the cargo via the hydrolysis of the starch gate in the presence of pancreatin, while $\mathbf{S 3}$ was expected to be opened by the rupture of the lipid bilayer induced by the presence of surfactant DTABr. In all cases, the solids remained capped in solution, whereas clear cargo delivery was observed in the presence of the corresponding stimulus (see Figure 2). Further tests, including the application of an unsuitable stimulus to the corresponding gated materials, resulted in no cargo delivery, which indicates the role of the gated ensembles in nanoparticles. For instance, $\mathbf{S 3}$ was able to deliver the cargo in the presence of DTABr, whereas $\mathbf{S 3}$ remained capped in the presence of pancreatin and TCEP. $\mathbf{S 2}$ was also confirmed to be unable to deliver its cargo in the presence of other enzymes other than pancreatin. Regarding the delivery profile, differences were found between the distinct capped MSNs. Figure 2 shows that dye delivery was relatively fast for $\mathbf{S 1}$ and $\mathbf{S 3}$ (80\% of the total delivered cargo was released in under $20 \mathrm{~min}$ ), whereas a slower cargo release was observed for $\mathbf{S 2}$ ( $80 \%$ of the total dye delivered was released after $c a$. 2-4 h). Besides Figure 2D also showed the crucial role played by the gating ensemble in the stimuli controlled release performances of $\mathbf{S 1}, \mathbf{S 2}$ and $\mathbf{S 3}$ nanoparticles. As could be seen, a nearly instantaneous safranin O release from uncapped MCM-41 nanoparticles was obtained. 

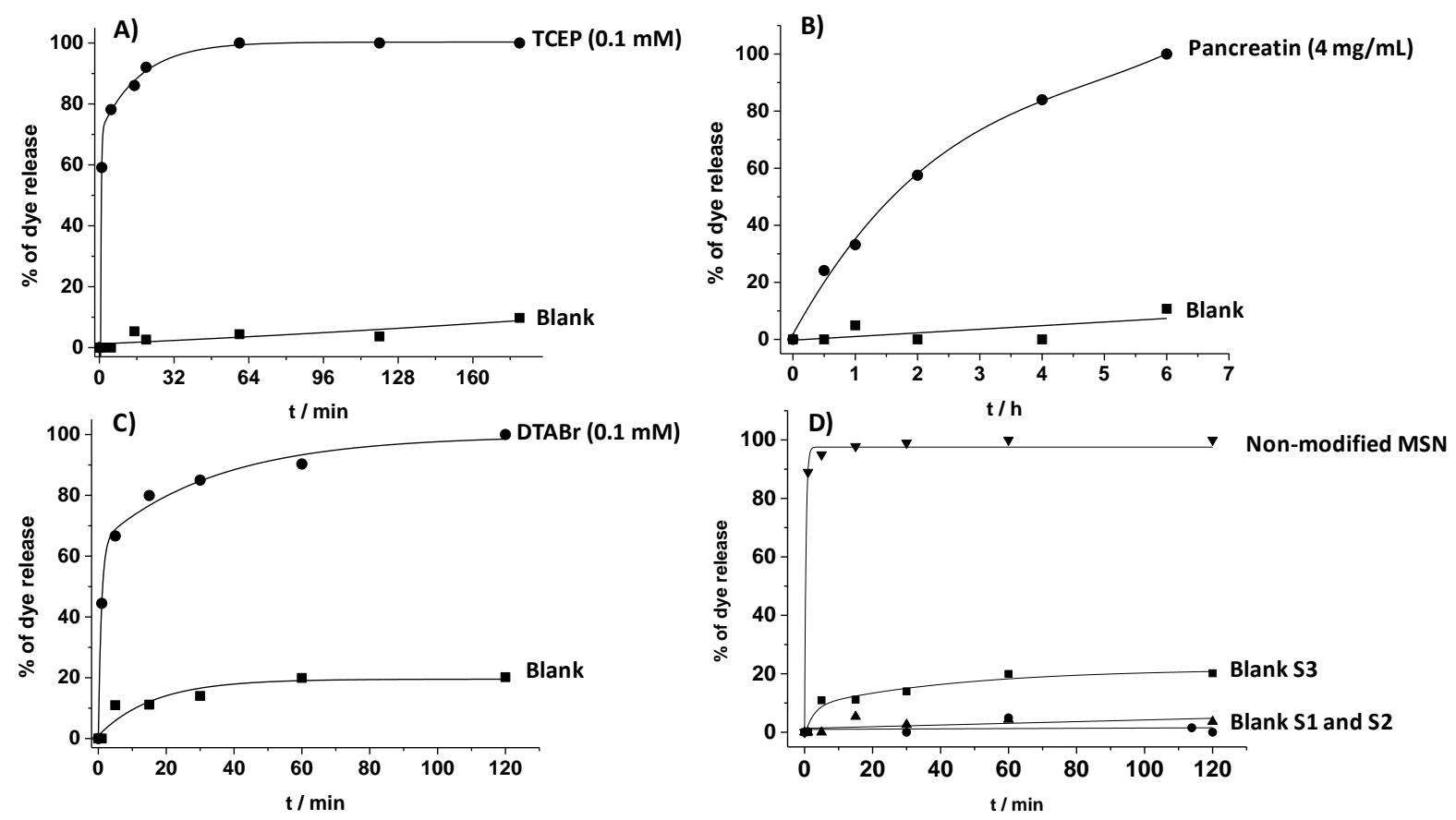

Figure 2. Safranin O release profile from A) S1, B) $\mathbf{S 2}$ and C) $\mathbf{S 3}$ in the absence or presence of the corresponding stimuli (TCEP $(0.1 \mathrm{mM})$, pancreatin $(4 \mathrm{mg} / \mathrm{mL})$ and DTABr $(0.1 \mathrm{mM})$ respectively). D) Safranin O release profile from a loaded uncapped MSN and S1, S2 and S3 in the absence of the corresponding stimuli.

A similar behavior in gate opening terms was expected to occur for solids S1, S2 and S3 (vide infra) upon analogous stimuli in a physiological context. In fact a number of studies have demonstrated that MSNs are easily endocytosed by cells, and S1, S2 and $\mathbf{S 3}$ are expected to deliver their cargo via the stimuli present in cells. ${ }^{18}$ For instance, $\mathbf{S 1}$ is expected to be opened upon internalization in cells by glutathione (a reducing agent at a high concentration in cells), whereas $\mathbf{S 2}$ would open through the hydrolysis of the starch gate due to the presence of amylases in lysosomes. $\mathbf{S 3}$ is also expected to deliver the cargo in cells upon the fusion of the cell membrane with the lipid bilayer (vide infra).

\subsection{In vitro cytotoxicity studies}

Caco- 2 cell cultures were used herein to perform cytotoxicity studies when using the different nanoparticles. Caco-2 cell viability in the presence of the starting bare MSNs and final capped solids $\mathbf{S 1}, \mathbf{S} 2$ and $\mathbf{S 3}$, at a concentration of $1 \mathrm{mg} / \mathrm{mL}$, was evaluated by MTT assays. Cell survival was evaluated at $24 \mathrm{~h}, 48 \mathrm{~h}$ and $72 \mathrm{~h}$, and the results are 
depicted in Figure 3. The data in the figure suggest that silica nanoparticles (both coated and uncoated) did not affect cell growth compared to the control values at $24 \mathrm{~h}$. The cytotoxicity effect of $10 \mu \mathrm{M}$ free doxorubicin was compared to all the materials. The drug served as a positive control in order to demonstrate the safety of the silica materials. At the longer times of 48 and $72 \mathrm{~h}$, presence of MSNs or S1-S3 nanoparticles barely had any influence on cell growth. Remarkably, the cells incubated with S2 showed the best survival results among all the solids, with survival values close to $100 \%$ at $72 \mathrm{~h}$. These results were better than those obtained when cells were incubated with $\mathbf{S 1}$ or S3, with survival near to $80 \%$, and were also higher than the cells incubated with bare MSNs, with survival close to $90 \%$ at $72 \mathrm{~h}$.

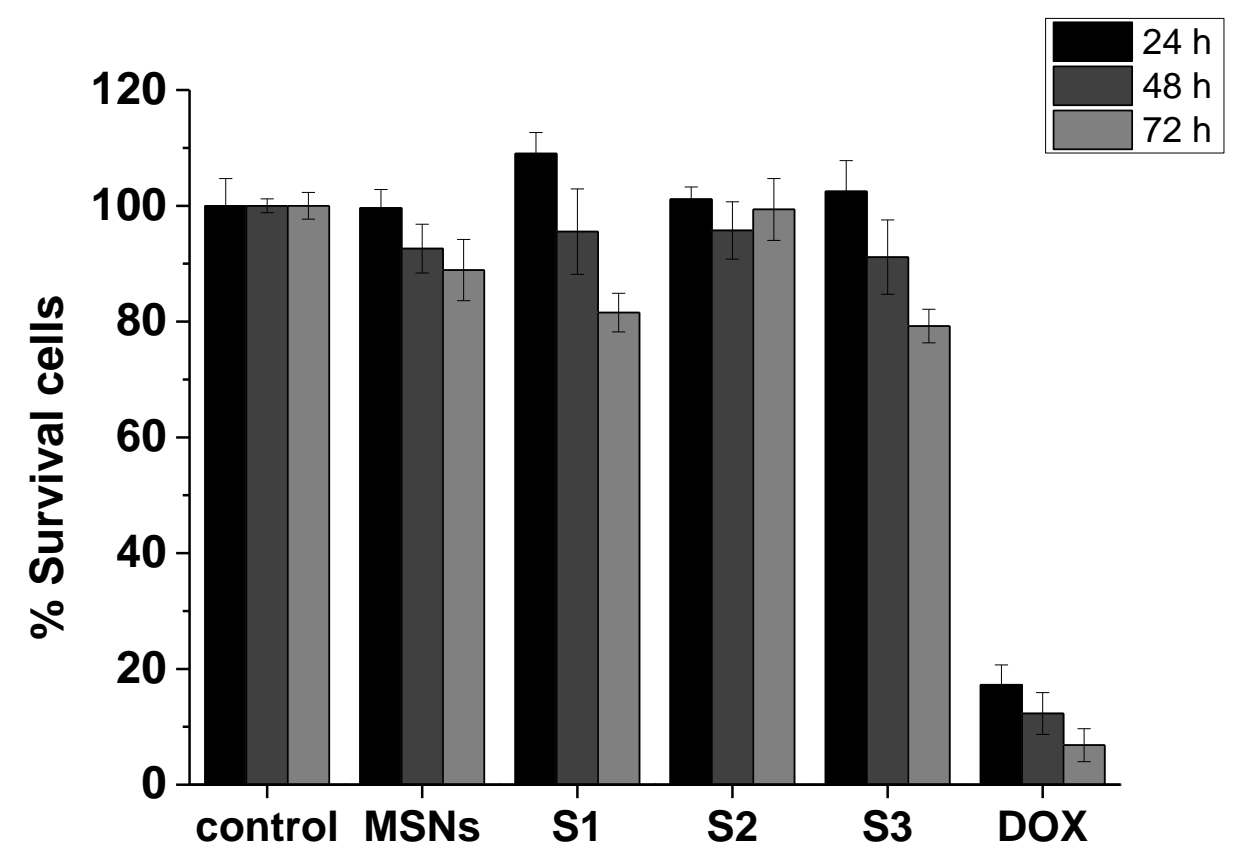

Figure 3. Percentage of Caco-2 cells survival after treatment with MSNs, S1, S2, S3 and with free doxorubicin (as positive control) for 24,48 or $72 \mathrm{~h}$. Data represent the means of the experiments performed in quadruplicate.

\subsection{In vitro permeability results}

Transport studies 
Caco-2 cell monolayers (a standard model for drug transport across the intestinal mucosa) were used herein to test the permeability of safranin $O$ when encapsulated in S1, S2 and S3, compared to that of free dye. Specifically, transport studies of free safranin $\mathrm{O}$ and encapsulated within nanoparticles S1, S2 and $\mathbf{S 3}(1 \mathrm{mg} / \mathrm{mL})$ were studied at an equivalent dye concentration. Safranin O content was measured in both the cell monolayer and receptor compartment. Figure 4 shows the percentage of safranin $\mathrm{O}$ measured in these compartments according to time.
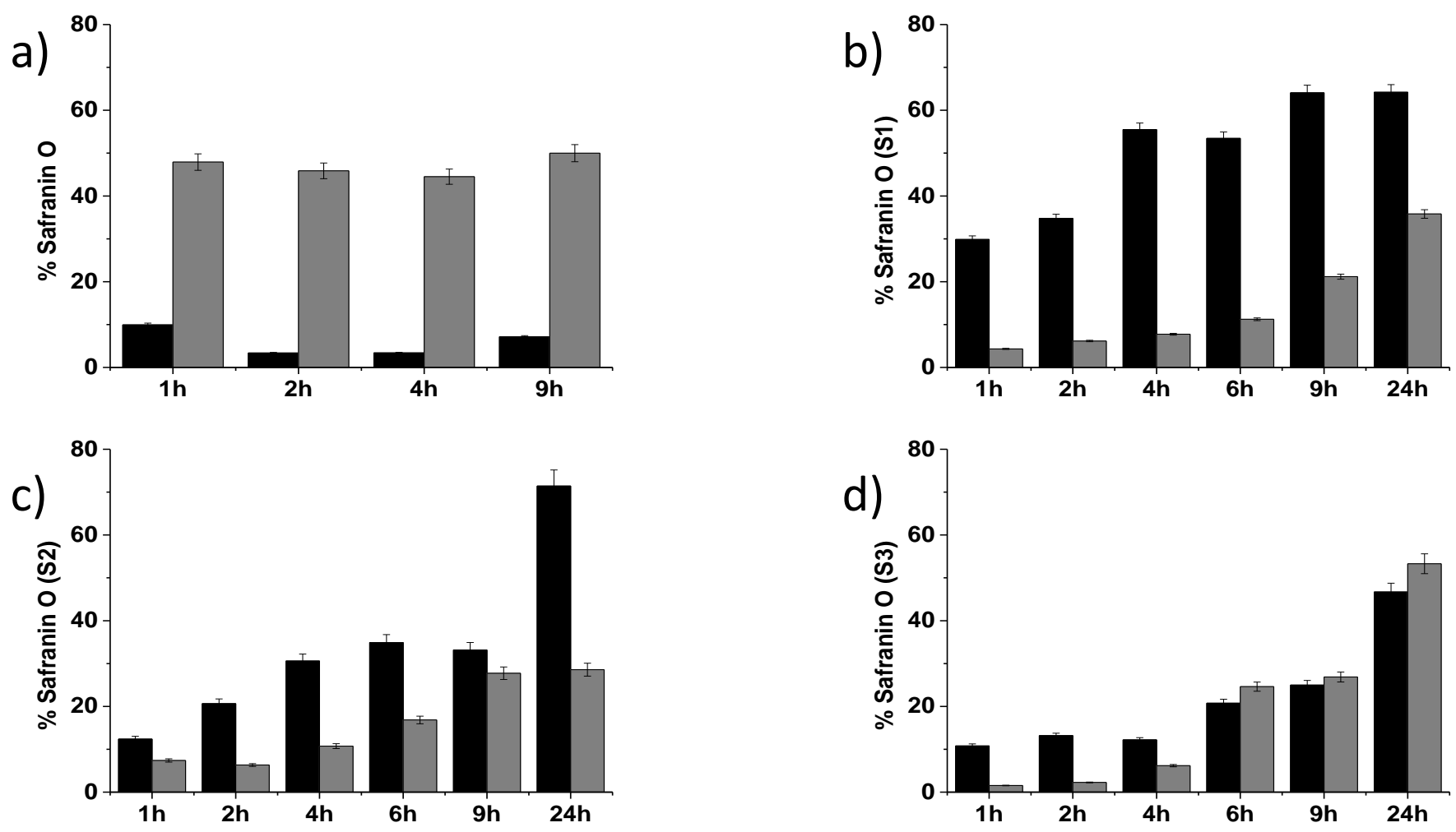

Figure 4. Percentage of safranin $\mathrm{O}$ in monolayer (black) and in the receptor compartment (grey) obtained from apical to basal (Pab) assays at different times in the Caco-2 cell line. a) free safranin O; b) safranin O encapsulated in solid S1 c) safranin O encapsulated in solid S2; d) safranin O encapsulated in solid S3. Data correspond to the values of three independent experiments. 
Free dye rapidly diffuses through the cell monolayer (see Figure 4a), as expected since it is a hydrophilic substance. In this case, the safranin $\mathrm{O}$ values in the receptor compartment were very high compared to the values in the monolayer at all times. The safranin $\mathrm{O}$ concentrations in the monolayer and receiving compartment did not vary with time after $1 \mathrm{~h}$ of free dye administration in the donor compartment, which indicates that the equilibrium was quickly reached in the system. Under these conditions the amount of safranin $\mathrm{O}$ inside cells was very small in all cases (data for the monolayer in Figure 4a). However, when safranin $\mathrm{O}$ was encapsulated, the distribution of the drug into the monolayer and receptor compartment was quite different and changed over time (see Figure 4b, 4c and 4d). The main difference between using free and encapsulated safranin O in S1, S2 and $\mathbf{S 3}$ was that dye delivery from nanoparticles could occur only within cells after endocytosis in the presence of the corresponding stimulus. As commented above, $\mathbf{S 1}$ opened and delivered the cargo in the presence of a reducing agent (most likely glutathione inside cells), whereas it was the presence of amylase enzyme that induced cargo release in the $\mathbf{S} 2$ nanoparticles via the hydrolysis of capping starch into glucose. At a certain time, the amount of delivered cargo in cells was governed by endocytosis kinetics, which was expected to be similar in $\mathbf{S 1}$ and $\mathbf{S 2}$, and by the uncapping process. For S1, the reduction of disulfide bonds was rather quick (Figure 3), whereas delivery from $\mathbf{S 2}$ was expected to depend on the amylase concentration and enzyme activity, and was slower. For S3, delivery occurred when the capping lipid bilayer merged with the cell membrane and nanoparticles internalization was achieved. For all the nanoparticles, part of the cargo, after delivery inside cells, was capable of crossing the basolateral membrane of Caco- 2 cells and reaching the receiving compartment, which mimics plasma (data shown as the receptor in Figure 4).

In terms of safranin O intracellular levels in the Caco-2 monolayer, higher values were found when using nanoparticles compared with the values found when dye was not encapsulated. The largest cargo levels inside cells after $24 \mathrm{~h}$ was observed when using coated MSNs $\mathbf{S 1}$ and $\mathbf{S 2}$.

One goal in local diseases that affect the colon is to be able to deliver high levels of the drug in the affected tissue (e.g., in tumors, inflamed tissues, etc.) to prevent drug transport across the intestinal barrier in order to improve the efficacy of therapeutics, 
reduce systemic toxicity and minimize adverse effects. In this context, our results suggested that solids $\mathbf{S 1}, \mathbf{S 2}$ and $\mathbf{S 3}$ allowed the amount of cargo inside cells to significantly increase by minimizing, at the same time, the quantity of cargo that reached the receptor compartment. Among the tested solids, nanoparticles $\mathbf{S 2}$ were selected to perform additional in vitro and in vivo assays to demonstrate that targeting delivery in colon can be achieved. S2 nanoparticles seemed the best option since they showed optimal cells survival (cytotoxicity assays, vide ante) and displayed high cargo delivery inside cells at $24 \mathrm{~h}$.

\section{Intracellular uptake and uptake mechanism}

Further assays with S2 and the Caco-2 monolayers, involving fluorescence images from Caco-2 incubated with these nanoparticles, showed a rather low fluorescence in cells due to safranin $\mathrm{O}$ after 1-2 h, whereas the dye concentrations in cells clearly increased with incubation time (see Figure 5). These data agree with the results observed in the in vitro transport assays (see Figure 4c). Moreover, in order to corroborate that Caco-2 cells endocytosed nanoparticles, similar fluorescence images were taken when the fluorescein-labeled $\mathbf{S 2 b}$ solid (fluorescein was covalently attached to nanoparticles) was used (see also Figure 5). This experiment clearly indicated that the amount of nanoparticles inside cells increased with time and a clear difference in fluorescence was observed when comparing images at $1 \mathrm{~h}$ and $24 \mathrm{~h}$.

S2b solid

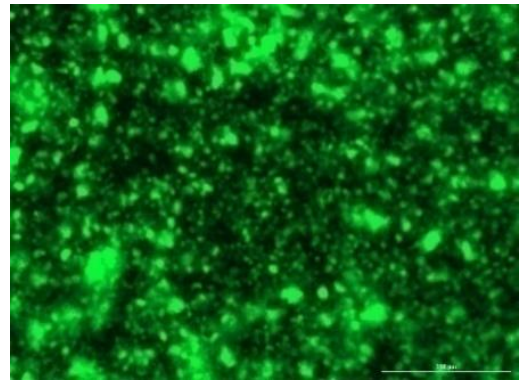

$1 \mathrm{~h}$

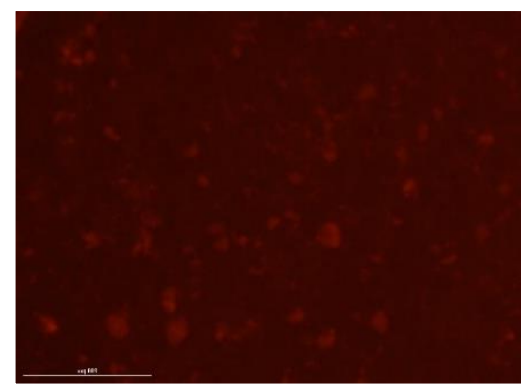

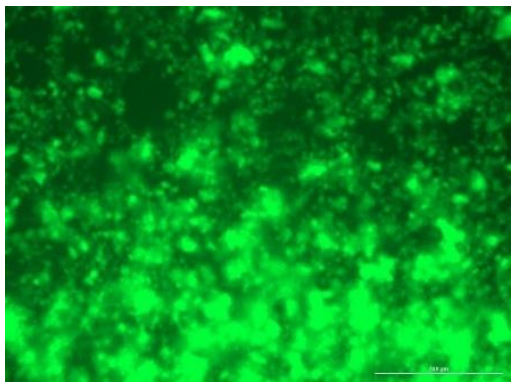

$24 \mathrm{~h}$

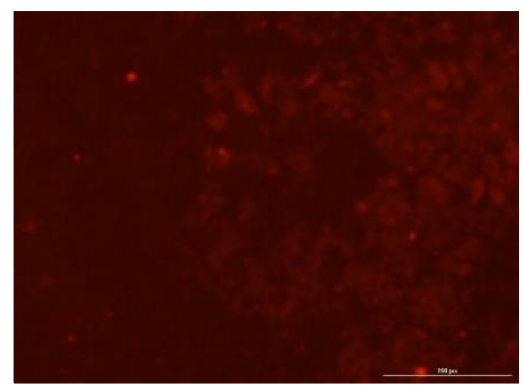


$1 \mathrm{~h}$

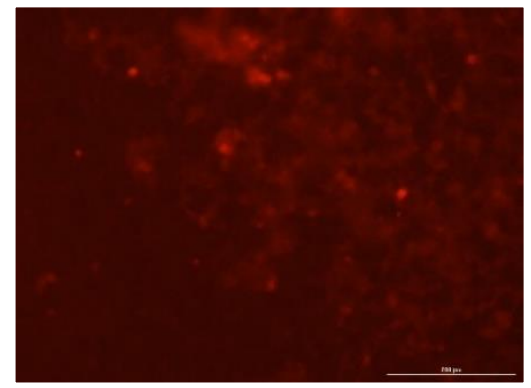

$4 \mathrm{~h}$

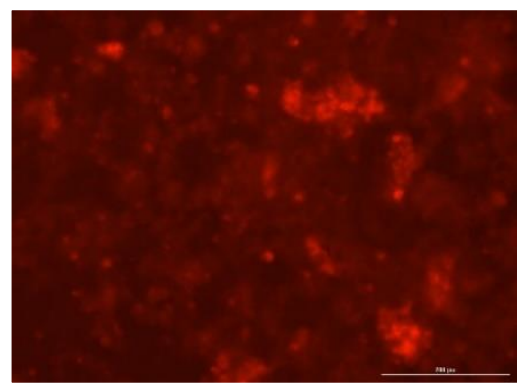

$12 \mathrm{~h}$
$2 \mathrm{~h}$

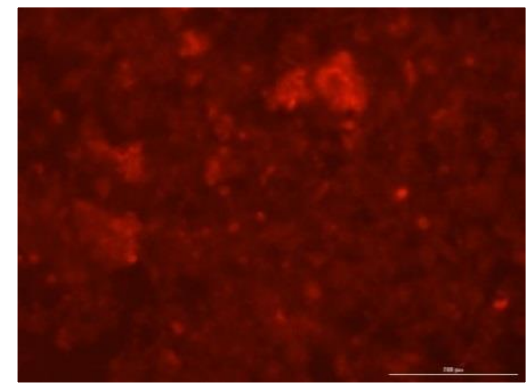

$9 \mathrm{~h}$

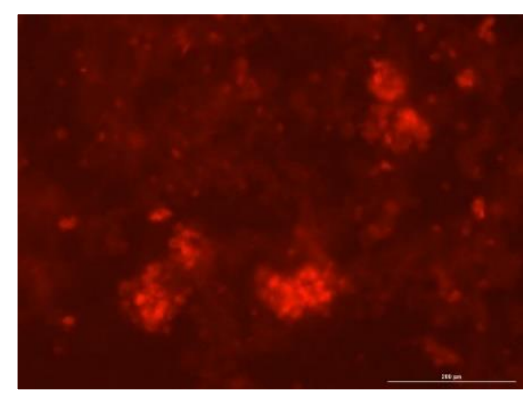

$24 \mathrm{~h}$

Figure 5. Fluorescence images obtained from the Caco-2 monolayer incubated with the S2b nanoparticles after 1 and $24 \mathrm{~h}$. Fluorescence images obtained from the Caco-2 monolayers incubated with S2 nanoparticles after 1, 2, 4, 9, 12 and $24 \mathrm{~h}$. 
It is known that internalization inside cells can be carried out by several mechanisms, such as clathrin-mediated endocytosis, caveolae-mediated endocytosis and caveolaeindependent endocytosis. ${ }^{55-57}$ In order to gain insight into the internalization of $\mathbf{S 2}$, the effect of several inhibitors (e.g. chlorpromazine, nystatin, or the methyl- $\beta$-cyclodextrin + lovastatin mixture) in the uptake of the nanoparticles in Caco-2 monolayers was studied. In particular, Figure 6 shows the amount of safranin O (delivered from S2) in the monolayer compartment in both the absence and presence of inhibitors after $2 \mathrm{~h}$. As seen, the safranin $\mathrm{O}$ concentration in the monolayer lowered by more than $50 \%$ in the presence of chlorpromazine and nystatin, whereas this value became even larger (up to $80 \%$ ) in the presence of methyl- $\beta$-cyclodextrin + lovastatin. These results clearly show that nanoparticles enter cells via endocytosis and suggest that several endocytosis mechanisms are active at the same time.

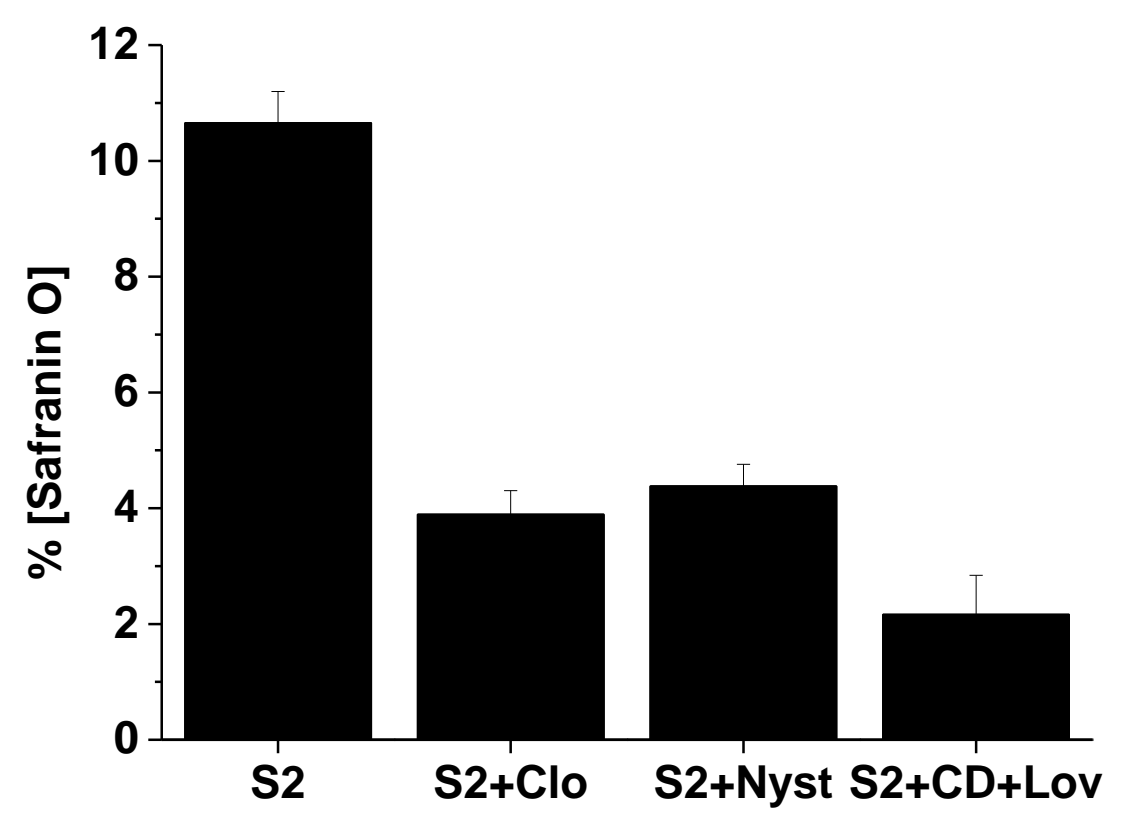

Figure 6. Percentage of safranin $\mathrm{O}$ in the cell monolayer when $\mathbf{S 2}$ was placed in the apical compartment in the absence and presence of the inhibitors of the different mechanisms of endocytosis (Chlor: chlorpromazine; Nyst: nystatin; $\mathrm{M} \beta \mathrm{CD}+$ Lov: methyl- $\beta$-cyclodextrin + lovastatin).

\subsection{In vivo tissue distribution studies}

Caco-2 monolayers are a standard model for drug transport across the intestinal mucosa. Nevertheless, the use of in vitro models has limitations since physiologically relevant 
factors are not easy to incorporate in the models such as the composition and $\mathrm{pH}$ of GI fluid, the gastric emptying, GI motility, mucus covering epithelium and blood and lymph flow. ${ }^{15}$ Therefore, in this section in vivo experiments in rats with Eudragit@FS 30 D coated capsules filled with $\mathbf{S 2}$ solid (the two step system) to study biodistribution of the cargo (i.e. safranin O) were carried out. Moreover, in order to obtain a targeted system to the colon tissue, $\mathbf{S 2}$ were included in an enteric coated capsule with Eudragit@FS 30 D. Coating with Eudragit polymers is a well-established procedure in oral administration to target a drug to a particular intestinal segment based on the solubility of the polymer at the prevailing $\mathrm{pH}$ on the segment of interest, in this case the colon. With this purpose the nanoparticles were incorporated in an enteric coated form as the "first step" of the targeting strategy. Once in colon, it was expected the capped MSNs to accumulate into the tissue. Nanoparticles delivered their cargo inside de colonic cells after the exposition to the enzymatic stimuli (second step). An enhanced safranin O delivery in the colon was expected when using $\mathbf{S 2}$ when compared with the dye administered free as solution. In these studies, free and encapsulated dye within the nanoparticles $\mathbf{S 2}(1 \mathrm{mg} / \mathrm{mL})$ were used at an equivalent concentration of safranin $\mathrm{O}$.

A comparison of safranin $\mathrm{O}$ distribution at $24 \mathrm{~h}$ in the colon, plasma and other organs (e.g. heart, pancreas, brain, kidney, spleen, liver and lung) in rats fed with a dye solution or with the S2-Eudragit ${ }^{\circledR} F S 30$ D formulation is depicted in Figure 7. The results showed that when safranin $\mathrm{O}$ was administered free, it did not accumulate in the colon or in other organs, and was almost completely eliminated after $24 \mathrm{~h}$. In contrast, a high dye content in colon tissue at $24 \mathrm{~h}$ was observed when safranin $\mathrm{O}$ was administered with the S2-Eudragit ${ }^{\circledR} F S 30$ D formulation, whereas a very low content was found in blood and in other tissues. 


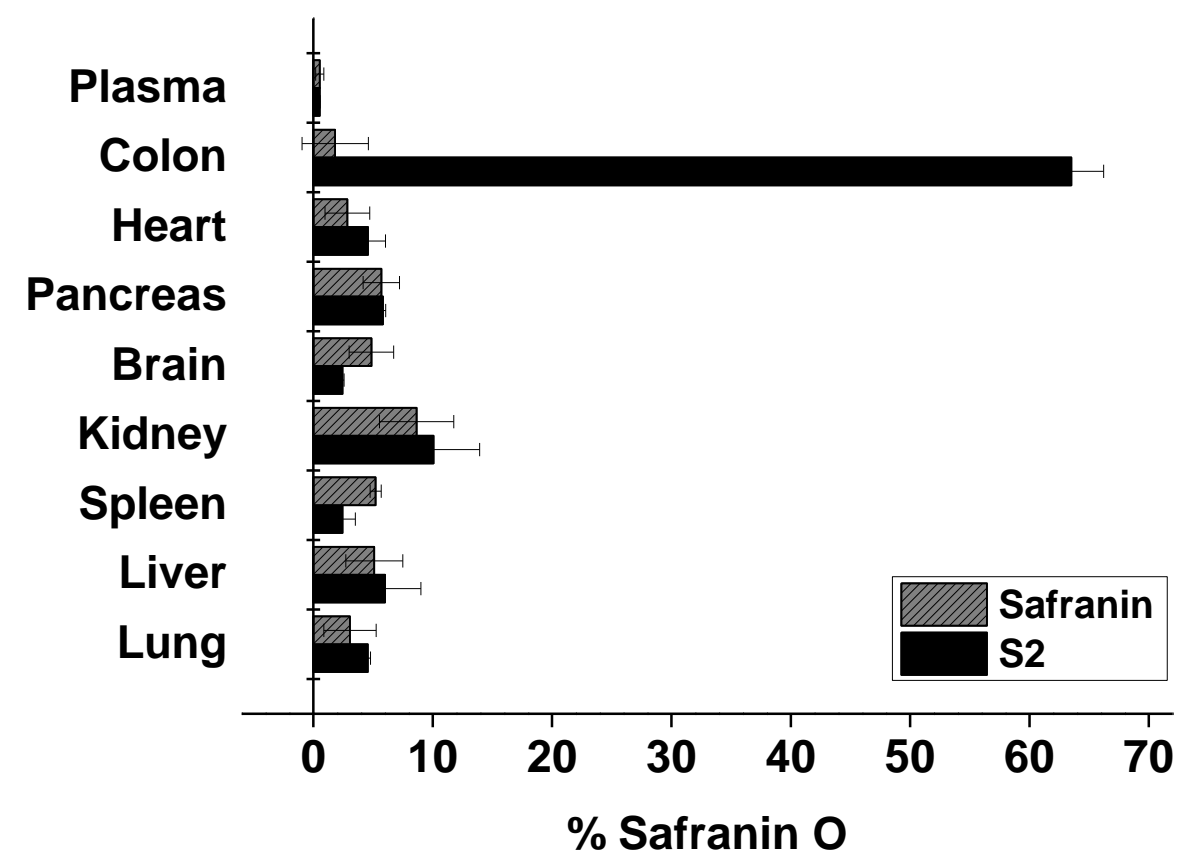

Figure 7. Percentage of safranin $\mathrm{O}$ distributed in plasma and the tested tissues at $24 \mathrm{~h}$ after free (grey) or dye encapsulated in the $\mathbf{S 2}$ solid in rats (black).

Safranin O distribution in the colon, plasma and other organs in rats fed with the S2Eudragit@FS 30 D formulation was studied at different times (e.g. 24 h, 48 h and $72 \mathrm{~h}$ ) after administration (see Figure 8). In this case the results indicated that safranin $\mathrm{O}$ retention in colon tissue was much greater than in plasma and other organs at both 24 and $48 \mathrm{~h}$ after administration. Moreover, the amount of safranin $\mathrm{O}$ in colon tissue significantly decreased at $72 \mathrm{~h}$. 


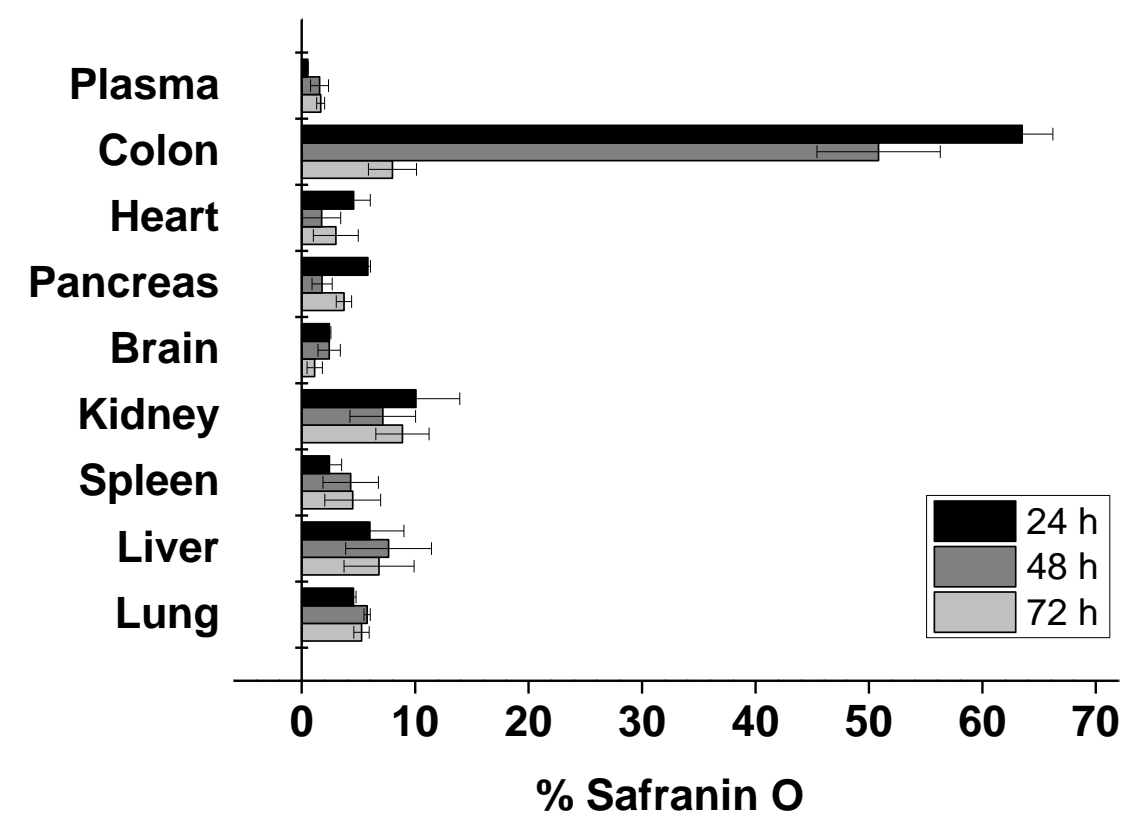

Figure 8. Percentage of safranin $\mathrm{O}$ in plasma and different tissues at 24 (black), 48 (dark grey) and $72 \mathrm{~h}$ (light grey) after $\mathbf{S 2}$ administration.

This enhanced distribution profile in the colon is highly desirable and beneficial for the administration of drugs that intend to exert effects on the colon, such as antiinflammatories, corticosteroids or immunosuppressant's for inflammatory bowel diseases, or antitumor drugs for colon cancer. Moreover, the low levels of the model drug (safranin O) found in plasma and other tissues would imply significantly fewer undesirable systemic effects.

\section{CONCLUSIONS}

Local treatment of colon diseases, such as IBD or colorectal cancer, is preferable to systemic treatment to avoid systemic toxic effects, while preserving therapeutic efficacy by providing high concentrations of the drug in the target tissue. In this work, we tested three different gated MSNs loaded with safranin $\mathrm{O}$ and capped with molecules that contained a disulphide bond (S1), hydrolyzed starch (S2) and a lipid bilayer (S3). In the laboratory studies, the prepared MSNs showed near "zero delivery", but were able to deliver cargo in the presence of the corresponding stimuli: (i) a reducing agent for $\mathbf{S 1}$, (ii) pancreatin for $\mathbf{S} 2$ and (iii) a surfactant for $\mathbf{S 3}$. These MSNs showed no significant 
toxicity in Caco- 2 cells up to $72 \mathrm{~h}$ at the $1 \mathrm{mg} / \mathrm{mL}$ concentration. Moreover, the permeability of safranin O when encapsulated in S1, S2 and S3, compared to that of free dye, in Caco-2 monolayers (a standard model for drug transport across the intestinal mucosa) demonstrated that free safranin O rapidly diffused through the cell monolayer, whereas intracellular dye levels were significantly higher in the Caco-2 monolayer when using MSNs S1, S2 or S3. In cells, $\mathbf{S 1}$ opened and delivered cargo due to the high glutathione concentration inside cells; presence of amylase enzymes in lysosomes accounted for cargo delivery from $\mathbf{S 2}$, whereas in $\mathbf{S 3}$, delivery occurred when the capping lipid bilayer became fused with the cell membrane. Internalization in the Caco2 cells of $\mathbf{S 2}$ and $\mathbf{S 2 b}$ (fluorescein-labeled MSNs) was demonstrated by fluorescence microscopy studies. Internalization assays with several inhibitors indicated that the $\mathbf{S 2}$ nanoparticles internalized via endocytosis, and suggested that several endocytosis mechanisms are active at the same time. Finally, in vivo experiments with $\mathbf{S} 2$ in rats to study cargo biodistribution (safranin $\mathrm{O}$ ) were carried out. To obtain a targeted system to colon tissue, $\mathbf{S 2}$ were included in an enteric coated capsule with Eudragit@FS 30 D. The results showed that when safranin O was encapsulated in the S2-Eudragit@FS 30 D formulation, the dye content in colon tissue was significantly high, and a very low amount was found in blood and in other organs. This was a very appropriate biodistribution and suggested that this, or similar formulations, using gated MSNs could be suitable systems for the targeted controlled drug delivery in the colon with enhanced therapeutic effects and minimum undesirable effects. It could be potentially applied to a wide range of diseases, such as colorectal cancer and IBD.

\section{ACKNOWLEDGEMENTS}

The authors acknowledge the financial support from the Spanish Government (Projects MAT2015-64139-C4-1-R and AGL2015-70235-C2-2-R) and the Generalitat Valenciana (Project GVA/2014/13).

\section{REFERENCES}

(1) Podolsky, D. K. Inflammatory Bowel Disease. N. Engl. J. Med. 2002, 347, 417429.

(2) Talley, N. J.; Abreu, M. T.; Achkar, J.-P.; Bernstein, C. N.; Dubinsky, M. C.; 
Hanauer, S. B.; Kane, S. V; Sandborn, W. J.; Ullman, T. A.; Moayyedi, P. An Evidence-Based Systematic Review on Medical Therapies for Inflammatory Bowel Disease. Am. J. Gastroenterol. 2011, 106, S2-S25.

(3) Torre, L. A.; Bray, F.; Siegel, R. L.; Ferlay, J.; Lortet-Tieulent, J.; Jemal, A. Global Cancer Statistics, 2012. CA. Cancer J. Clin. 2015, 65, 87-108.

(4) Family, L.; Xu, L.; Xu, H.; Cannavale, K.; Sattayapiwat, O.; Page, J. H.; Bohac, C.; Chao, C. The Effect of Chemotherapy-Induced Anemia on Dose Reduction and Dose Delay. Support. Care Cancer 2016, 24, 4263-4271.

(5) Ortiz, R.; Prados, J.; Melguizo, C.; Arias, J. L.; Ruíz, M. A.; Álvarez, P. J.; Caba, O.; Luque, R.; Segura, A.; Aránega, A. 5-Fluorouracil-Loaded Poly(epsilonCaprolactone) Nanoparticles Combined with Phage E Gene Therapy as a New Strategy against Colon Cancer. Int. J. Nanomedicine 2012, 7, 95-107.

(6) Jordan, B.; Jahn, F.; Beckmann, J.; Unverzagt, S.; Müller-Tidow, C.; Jordan, K. Calcium and Magnesium Infusions for the Prevention of Oxaliplatin-Induced Peripheral Neurotoxicity: A Systematic Review. Oncology 2016, 90, 299-306.

(7) Wardill, H. R.; Gibson, R. J.; Van Sebille, Y. Z. A.; Secombe, K. R.; Coller, J. K.; White, I. A.; Manavis, J.; Hutchinson, M. R.; Staikopoulos, V.; Logan, R. M.; Bowen, J. M. Irinotecan-Induced Gastrointestinal Dysfunction and Pain Are Mediated by Common TLR4-Dependent Mechanisms. Mol. Cancer Ther. 2016, $15,1376-1386$.

(8) Ibekwe, V. C.; Fadda, H. M.; Parsons, G. E.; Basit, A. W. A Comparative in Vitro Assessment of the Drug Release Performance of $\mathrm{pH}$-Responsive Polymers for Ileo-Colonic Delivery. Int. J. Pharm 2006, 308, 52-60.

(9) Maestrelli, F.; Cirri, M.; Corti, G.; Mennini, N.; Mura, P. Development of Enteric-Coated Calcium Pectinate Microspheres Intended for Colonic Drug Delivery. Eur. J. Pharm. Biopharm. 2008, 69, 508-518.

(10) Evans, D. F.; Pye, G.; Bramley, R.; Clark, A. G.; Dyson, T. J.; Hardcastle, J. D. Measurement of Gastrointestinal pH Profiles in Normal Ambulant Human Subjects. Gut 1988, 29, 1035-1041. 
(11) Rao, K. A.; Yazaki, E.; Evans, D. F.; Carbon, R. Objective Evaluation of Small Bowel and Colonic Transit Time Using pH Telemetry in Athletes with Gastrointestinal Symptoms. Br. J. Sports Med. 2004, 38, 482-487.

(12) Coupe, A. J.; Davis, S. S.; Wilding, I. R. Variation in Gastrointestinal Transit of Pharmaceutical Dosage Forms in Healthy Subjects. Pharm. Res. 1991, 8, 360364.

(13) Sangalli, M. E.; Maroni, A.; Zema, L.; Busetti, C.; Giordano, F.; Gazzaniga, A. In Vitro and in Vivo Evaluation of an Oral System for Time And/or Site-Specific Drug Delivery. J. Control. Release 2001, 73, 103-110.

(14) Muraoka, M.; Hu, Z.; Shimokawa, T.; Sekino, S.; Kurogoshi, R.; Kuboi, Y.; Yoshikawa, Y.; Takada, K. Evaluation of Intestinal Pressure-Controlled Colon Delivery Capsule Containing Caffeine as a Model Drug in Human Volunteers. $J$. Control. Release 1998, 52, 119-129.

(15) Boegh, M.; Foged, C.; Müllertz, A.; Mørck Nielsen, H. Mucosal Drug Delivery: Barriers, in Vitro Models and Formulation Strategies. J. Drug Deliv. Sci. Technol. 2013, 23, 383-391.

(16) Kresge, C. T.; Leonowicz, M. E.; Roth, W. J.; Vartuli, J. C.; Beck, J. S. Ordered Mesoporous Molecular Sieves Synthesized by a Liquid-Crystal Template Mechanism. Nature 1992, 359, 710-712.

(17) Vivero-Escoto, J. L.; Slowing, I. I.; Trewyn, B. G.; Lin, V. S.-Y. Mesoporous Silica Nanoparticles for Intracellular Controlled Drug Delivery. Small 2010, 6, 1952-1967.

(18) Aznar, E.; Oroval, M.; Pascual, L.; Murguía, J. R.; Martínez-Máñez, R.; Sancenón, F. Gated Materials for On-Command Release of Guest Molecules. Chem. Rev. 2016, 116, 561-718.

(19) Sancenón, F.; Pascual, L.; Oroval, M.; Aznar, E.; Martínez-Máñez, R. Gated Silica Mesoporous Materials in Sensing Applications. ChemistryOpen 2015, 4, $418-437$. 
(20) Muñoz, B.; Rámila, A.; Pérez-Pariente, J.; Díaz, I.; Vallet-Regí, M. MCM-41

Organic Modification as Drug Delivery Rate Regulator. Chem. Mater. 2003, 15, $500-503$.

(21) Aznar, E.; Martínez-Máñez, R.; Sancenón, F. Controlled Release Using Mesoporous Materials Containing Gate-like Scaffoldings. Expert Opin. Drug Deliv. 2009, 6, 643-655.

(22) Casasús, R.; Climent, E.; Marcos, M. D.; Martínez-Máñez, R.; Sancenón, F.; Soto, J.; Amorós, P.; Cano, J.; Ruiz, E. Dual Aperture Control on pH- and AnionDriven Supramolecular Nanoscopic Hybrid Gate-like Ensembles. J. Am. Chem. Soc. 2008, 130, 1903-1917.

(23) Coll, C.; Casasús, R.; Aznar, E.; Marcos, M. D.; Martínez-Máñez, R.; Sancenón, F.; Soto, J.; Amorós, P. Nanoscopic Hybrid Systems with a Polarity-Controlled Gate-like Scaffolding for the Colorimetric Signalling of Long-Chain Carboxylates. Chem. Commun. 2007, 1957-1959.

(24) Casasús, R.; Aznar, E.; Marcos, M. D.; Martínez-Máñez, R.; Sancenón, F.; Soto, J.; Amorós, P. New Methods for Anion Recognition and Signaling Using Nanoscopic Gatelike Scaffoldings. Angew. Chemie Int. Ed. 2006, 45, 6661-6664.

(25) He, X.; Zhao, Y.; He, D.; Wang, K.; Xu, F.; Tang, J. ATP-Responsive Controlled Release System Using Aptamer-Functionalized Mesoporous Silica Nanoparticles. Langmuir 2012, 28, 12909-12915.

(26) Özalp, V. C.; Schäfer, T. Aptamer-Based Switchable Nanovalves for StimuliResponsive Drug Delivery. Chem Eur. J. 2011, 17, 9893-9896.

(27) Torney, F.; Trewyn, B. G.; Lin, V. S.-Y.; Wang, K. Mesoporous Silica Nanoparticles Deliver DNA and Chemicals into Plants. Nat. Nanotechnol. 2007, $2,295-300$.

(28) Radu, D. R.; Lai, C.-Y.; Jeftinija, K.; Rowe, E. W.; Jeftinija, S.; Lin, V. S.-Y. A Polyamidoamine Dendrimer-Capped Mesoporous Silica Nanosphere-Based Gene Transfection Reagent. J. Am. Chem. Soc. 2004, 126, 13216-13217. 
(29) Mortera, R.; Vivero-Escoto, J.; Slowing, I. I.; Garrone, E.; Onida, B.; Lin, V. S.Y. Cell-Induced Intracellular Controlled Release of Membrane Impermeable Cysteine from a Mesoporous Silica Nanoparticle-Based Drug Delivery System. Chem. Commun. 2009, 36, 3219-3221.

(30) Hernandez, R.; Tseng, H.-R.; Wong, J. W.; Stoddart, J. F.; Zink, J. I. An Operational Supramolecular Nanovalve. J. Am. Chem. Soc. 2004, 126, 3370 3371 .

(31) Nguyen, T. D.; Liu, Y.; Saha, S.; Leung, K. C.-F.; Stoddart, J. F.; Zink, J. I. Design and Optimization of Molecular Nanovalves Based on Redox-Switchable Bistable Rotaxanes. J. Am. Chem. Soc. 2007, 129, 626-634.

(32) Lai, C.-Y.; Trewyn, B. G.; Jeftinija, D. M.; Jeftinija, K.; Xu, S.; Jeftinija, S.; Lin, V. S.-Y. A Mesoporous Silica Nanosphere-Based Carrier System with Chemically Removable CdS Nanoparticle Caps for Stimuli-Responsive Controlled Release of Neurotransmitters and Drug Molecules. J. Am. Chem. Soc. 2003, $125,4451-4459$.

(33) Climent, E.; Bernardos, A.; Martínez-Máñez, R.; Maquieira, A.; Marcos, M. D.; Pastor-Navarro, N.; Puchades, R.; Sancenón, F.; Soto, J.; Amorós, P. Controlled Delivery Systems Using Antibody-Capped Mesoporous Nanocontainers. J. Am. Chem. Soc. 2009, 131, 14075-14080.

(34) Climent, E.; Martínez-Máñez, R.; Maquieira, Á.; Sancenón, F.; Marcos, M. D.; Brun, E. M.; Soto, J.; Amorós, P. Antibody-Capped Mesoporous Nanoscopic Materials: Design of a Probe for the Selective Chromo-Fluorogenic Detection of Finasteride. ChemistryOpen 2012, 1, 251-259.

(35) Zhang, B.; Liu, B.; Liao, J.; Chen, G.; Tang, D. Novel Electrochemical Immunoassay for Quantitative Monitoring of Biotoxin Using Target-Responsive Cargo Release from Mesoporous Silica Nanocontainers. Anal. Chem. 2013, 85, 9245-9252.

(36) Gao, Z.; Tang, D.; Xu, M.; Chen, G.; Yang, H. Nanoparticle-Based Pseudo Hapten for Target-Responsive Cargo Release from a Magnetic Mesoporous Silica Nanocontainer. Chem. Commun. 2014, 50, 6256-6258. 
(37) Climent, E.; Martínez-Máñez, R.; Sancenón, F.; Marcos, M. D.; Soto, J.;

Maquieira, A.; Amorós, P. Controlled Delivery Using Oligonucleotide-Capped

Mesoporous Silica Nanoparticles. Angew. Chemie Int. Ed. 2010, 49, 7281-7283.

(38) Climent, E.; Mondragón, L.; Martínez-Máñez, R.; Sancenón, F.; Marcos, M. D.;

Murguía, J. R.; Amorós, P.; Rurack, K.; Pérez-Payá, E. Selective, Highly

Sensitive, and Rapid Detection of Genomic DNA by Using Gated Materials:

Mycoplasma Detection. Angew. Chemie Int. Ed. 2013, 52, 8938-8942.

(39) Pu, F.; Liu, Z.; Ren, J.; Qu, X. Nucleic Acid-mesoporous Silica Nanoparticle Conjugates for Keypad Lock Security Operation. Chem. Commun. 2013, 49, 2305-2307.

(40) Oroval, M.; Climent, E.; Coll, C.; Eritja, R.; Aviñó, A.; Marcos, M. D.; Sancenón, F.; Martínez-Máñez, R.; Amorós, P. An Aptamer-Gated Silica Mesoporous Material for Thrombin Detection. Chem. Commun. 2013, 49, 54805482.

(41) Patel, K.; Angelos, S.; Dichtel, W. R.; Coskun, A.; Yang, Y. W.; Zink, J. I.; Stoddart, J. F. Enzyme-Responsive Snap-Top Covered Silica Nanocontainers. $J$. Am. Chem. Soc. 2008, 130, 2382-2383.

(42) Bernardos, A.; Aznar, E.; Marcos, M. D.; Martínez-Máñez, R.; Sancenón, F.; Soto, J.; Barat, J. M.; Amorós, P. Enzyme-Responsive Controlled Release Using Mesoporous Silica Supports Capped with Lactose. Angew. Chemie Int. Ed. 2009, $48,5884-5887$.

(43) Llopis-Lorente, A.; Lozano-Torres, B.; Bernardos, A.; Martínez-Máñez, R.; Sancenón, F. Mesoporous Silica Materials for Controlled Delivery Based on Enzymes . J. Mater. Chem. B. 2017, 5, 3069-3083.

(44) Zhang, Z.; Balogh, D.; Wang, F.; Sung, S. Y.; Nechushtai, R.; Willner, I. Biocatalytic Release of an Anticancer Drug from Nucleic-Acids-Capped Mesoporous $\mathrm{SiO}_{2}$ Using DNA or Molecular Biomarkers as Triggering Stimuli. ACS Nano 2013, 7, 8455-8468.

(45) Giménez, C; de la Torre, C.; Gorbe, M; Aznar, E.; Sancenón, F.; Murguía, J. R.; 
Martínez-Máñez, M.; Marcos, M. D.; Amorós, P. Gated Mesoporous Silica Nanoparticles for the Controlled Delivery of Drugs in Cancer Cells. Langmuir 2015, 31, 3753-3762.

(46) Ashley, C. E.; Carnes, E. C.; Phillips, G. K.; Padilla, D.; Durfee, P. N.; Brown, P. A.; Hanna, T. N.; Liu, J.; Phillips, B.; Carter, M. B.; Carroll, N. J.; Jiang, X.; Dunphy, D. R.; Willman, C. L.; Petsev, D. N.; Evans, D. G.; Parikh, A. N.; Chackerian, B.; Wharton, W.; Peabody, D. S.; Brinker, C. J. The Targeted Delivery of Multicomponent Cargos to Cancer Cells via Nanoporous ParticleSupported Lipid Bilayers. Nature Mat. 2011, 10, 389-397.

(47) Hilgers, A. R.; Conradi, R. A.; Burton, P. S. Caco-2 Cell Monolayers as a Model for Drug Transport across the Intestinal Mucosa. Pharm. Res. 1990, 7, 902-910.

(48) Lozoya-Agullo, I.; González-Álvarez, I.; González-Álvarez, M.; MerinoSanjuán, M.; Bermejo, M. In Situ Perfusion Model in Rat Colon for Drug Absorption Studies: Comparison with Small Intestine and Caco-2 Cell Model. J. Pharm. Sci. 2015, 104, 3136-3145.

(49) Mosmann, T. Rapid Colorimetric Assay for Cellular Growth and Survival: Application to Proliferation and Cytotoxicity Assays. J. Immunol. Methods 1983, $65,55-63$.

(50) Oltra-Noguera, D.; Mangas-Sanjuan, V.; Centelles-Sangüesa, A.; GonzalezGarcia, I.; Sanchez-Castaño, G.; Gonzalez-Alvarez, M.; Casabo, V.-G.; Merino, V.; Gonzalez-Alvarez, I.; Bermejo, M. Variability of Permeability Estimation from Different Protocols of Subculture and Transport Experiments in Cell Monolayers. J. Pharmacol. Toxicol. Methods 2015, 71, 21-32.

(51) González-Alvarez, I.; Fernández-Teruel, C.; Garrigues, T. M.; Casabo, V. G.; Ruiz-García, A.; Bermejo, M. Kinetic Modelling of Passive Transport and Active Efflux of a Fluoroquinolone across Caco-2 Cells Using a Compartmental Approach in NONMEM. Xenobiotica 2005, 35, 1067-1088.

(52) Hu, M.; Chen, J.; Tran, D.; Zhu, Y.; Leonardo, G. The Caco-2 Cell Monolayers as an Intestinal Metabolism Model: Metabolism of Dipeptide Phe-Pro. J. Drug Target. 1994, 2, 79-89. 
(53) Hu, M.; Chen, J.; Zhu, Y.; Dantzig, A. H.; Stratford, R. E.; Kuhfeld, M. T. Mechanism and Kinetics of Transcellular Transport of a New Beta-Lactam Antibiotic Loracarbef across an Intestinal Epithelial Membrane Model System (Caco-2). Pharm. Res. 1994, 11, 1405-1413.

(54) Hidalgo, I. J.; Raub, T. J.; Borchardt, R. T. Characterization of the Human Colon Carcinoma Cell Line (Caco-2) as a Model System for Intestinal Epithelial Permeability. Gastroenterology 1989, 96, 736-749.

(55) Beloqui, A.; Solinís, M. Á.; Gascón, A. R.; del Pozo-Rodríguez, A.; des Rieux, A.; Préat, V. Mechanism of Transport of Saquinavir-Loaded Nanostructured Lipid Carriers across the Intestinal Barrier. J. Control. Release 2013, 166, 115123.

(56) Hillaireau, H.; Couvreur, P. Nanocarriers' Entry into the Cell: Relevance to Drug Delivery. Cell. Mol. Life Sci. 2009, 66, 2873-2896.

(57) Mathot, F.; des Rieux, A.; Ariën, A.; Schneider, Y.-J.; Brewster, M.; Préat, V. Transport Mechanisms of mmePEG750P(CL-Co-TMC) Polymeric Micelles across the Intestinal Barrier. J. Control. Release 2007, 124, 134-143. 